\section{Michael J. A. WOHL \\ Full Professor \\ Psychology}

\section{DEGREES}

Ph.D. Psychology

B.A. Psychology

Updated: 08 April 2023

\title{
EMPLOYMENT HISTORY
}

2014-

2007-2014

2003-2007
Full Professor

Associate Professor

Assistant Professor
University of Alberta

University of Winnipeg

2003

1998
Psychology

Psychology

Psychology

\section{Professional Honours}

Research of the Year Award, National Council on Problem Gambling, 2021

Scientific Achievement Award, National Center for Responsible Gaming, 2019

Fellow, Society of Personality and Social Psychology, 2018

Fellow, American Psychological Society, 2018

Research Achievement Award, Carleton University, 2017

Faculty Graduate Mentoring Award, Carleton University, 2017

University of Queensland Travel Award for International Collaborative Research, 2009

Research Achievement Award, Carleton University, 2008

Teaching Excellence Award, Carleton University Student's Association, 2008

Society for Personality and Social Psychology Student Travel Award, 2003

SSHRC Postdoctoral Fellowship, 2003-2005 (Declined)

Teaching Honour Roll, University of Alberta, 2003

Mary Louise Imrie Graduate Student Award, 2002

Teaching Honour Roll, University of Alberta, 2002

SSHRC Doctoral Fellowship, 2000-2003

Walter H. Johns Graduate Fellowship, 2000-2003

Graduate Studies and Research Award, University of Alberta, 1999-2000

\section{Current Research Interests}

Broadly, I have two independent lines of research:

1. Conflict Resolution: In this line of research, we examine the causes and consequences of harmdoing at both the interpersonal (one person transgressing against another) and intergroup level (historical and contemporary harm experienced by members of one group at the hands of another group). Of particular concern is the emotional reaction that stems from harming or being harmed (e.g., angst, guilt) and their effects on relations with others. For example, we have shown that collective angst (i.e., concern for the future viability of own's group) is as a strong motivator of group-based protective behaviour. This behaviour can either be constructive (e.g., donating time and money to your group) or destructive (e.g., support for aggression toward other groups). Ultimately, this research is aimed at advancing peace and reconciliation. As such, we also focus attention on the apology-forgiveness link and ways to make this link stronger.

2. Disordered Gambling: In this line of research, we examine factors that lead to excessive play (e.g., erroneous cognitions, craving) and means to increase responsible gambling (e.g., setting a limit on play). Recently, attention has been paid to the potential impact social casino gaming (i.e., free-to-play games on social network sites) and loyalty program membership can have on (responsible) gambling behaviour. We also conduct a great deal of research on how to help people who live with addiction overcome barriers to behavioural change. Primarily, this work focuses on the utility of nostalgic reverie for the pre-addicted self as a motivator for change. 


\section{Lifetime summary of scholarly dissemination}

\begin{tabular}{|l|l|}
\hline Category & Totals \\
\hline Chapters in books & 17 \\
\hline Papers in peer-reviewed journals & 171 \\
\hline Government or technical reports & 41 \\
\hline Journalistic writing & 2 \\
\hline Paper under review in peer-reviewed journals & 6 \\
\hline Abstracts or papers presented at academic conferences & 147 \\
\hline $\begin{array}{l}\text { Invited papers at academic conference or academic } \\
\text { institutions }\end{array}$ & 76 \\
\hline Invited presentations to non-academic institutions & 23 \\
\hline Academic conferences organized & 3 \\
\hline Academic symposia organized & 5 \\
\hline Symposia discussant & 2 \\
\hline Workshops & 17 \\
\hline
\end{tabular}

\section{Publications}

\section{Chapters in edited books (17)}

Orazani, S. N. \& Wohl, M. J. A. (2022). Collective angst. In R. L. Miller (Ed.). The Routledge research encyclopedia of psychology in the real world. London: Routledge Press. https://doi.org/10.4324/9780367198459-REPRW117-1

Stefaniak, A. \& Wohl, M. J. A. (2022). Collective nostalgia. In R. L. Miller (Ed.). The Routledge research encyclopedia of psychology in the real world. London: Routledge Press. https://doi.org/10.4324/9780367198459-REPRW12-1

Tabri, N., Wohl, M. J. A., \& Xuereb, S. (2021). Population-Based Safer Gambling/Responsible Gambling Efforts. In M. Hilbrecht (Ed.) Prevention and Education Evidence Review: Gambling-Related Harm (pp. 66-108). GREO. https://doi.org/10.33684/2021.006

Wohl, M. J. A \& Stefaniak, A. (2020). Collective nostalgia and the desire to make one's group great again. In J. P. Forgas, William D. Crano, and Klaus Fiedler (Eds.), Application of social psychology: How social psychology can contribute to the solution of real-world problems (Sydney Symposium of Social Psychology series). New York, NY, US: Psychology Press.

Kachanoff, F. J., Wohl, M. J. A. \& Taylor, D. M. (2020). Striking at the core: A unified framework of how collective victimhood affects basic psychological needs for relatedness, competence and autonomy. In J. R. Vollhardt (Ed.), The social psychology of collective victimhood (pp. 380-398). Oxford, UK: Oxford University Press. https://doi.org/10.1093/oso/9780190875190.003.0018

Wohl, M. J. A, Tabri, N., \& Halperin, E. (2020). Emotional sources of intergroup atrocities. In L. S. Newman (Ed.), Confronting humanity at its worst: The social psychology of genocide and extreme intergroup violence (pp. 91118). Oxford, UK: Oxford University Press.

Wohl, M. J. A., Salmon, M. M., Hollingshead, S. J., Lidstone, S., \& Tabri, N. (2017). The dark side of self forgiveness: Forgiving the self can impede change for ongoing, harmful behavior. In L. Woodyattt, E. Worthington Jr., M. Wenzel \& B. Griffin (Eds.), Handbook of the psychology of self-forgiveness (pp. 147-159). London: Springer. 
Branscombe, N. R., Wohl, M. J. A., \& Warner, R. (2016). Remembering historical victimization: Potential for intergroup conflict escalation and conflict reduction. In A. G. Miller (Eds.), The social psychology of good and evil, second edition (pp. 367-289). New York: Guilford Publishing.

Dupuis, D. R., Porat, R., \& Wohl, M. J. A. (2015). Collective Angst in Intractable Conflicts: How Concern for the Ingroup's Future Vitality Shapes Adversarial Intergroup Relations. In K. Sharvit \& E. Halperin (Eds.), The Social Psychology of Intractable Conflicts (pp. 131-142). Springer International Publishing.

Warren, K., Parush, A., Wohl, M. J. A., \& Kim, A. (2014). Embedded disruption in online slot machines facilitates responsible gambling. In Spagnolli A., Chittaro L., \& Gamberini L. (Eds.), Proceedings of persuasive technology 9th international conference, PERSUASIVE 2014, Padua, Italy, May 21-23, 2014. Lecture Notes in Computer Science, Vol. 8462 (pp. 253-265). London: Springer.

Wohl, M. J. A., Sztainert, T., \& Young, M. M. (2013). The CARE Model: How to Improve Industry-GovernmentHealth Care Provider Linkages. In D. Richards, L. Nower, \& A. Blaszczynski (Eds.), The Wiley-Blackwell Handbook of Disordered Gambling (pp. 263-282). John Wiley \& Sons Ltd.

Wohl, M. J. A., \& Branscombe, N.R. (2011). Guilt: Personal and collective. In D.J. Christie (Ed.), Encyclopedia of peace psychology (pp. 501-505). New York: Wiley-Blackwell.

Wohl, M. J. A. \& Pritchard, E. T. (2008). Elements of the triangle model of responsibility affect willingness to forgiveness: How context can influence our judgments of others. In B. P. Reimann (Ed.), Personality and social psychology research (pp. 75-92). New York: Nova Science Publishers, Inc.

Wohl, M. J. A., \& Branscombe, N. R. (2008). Collective angst: How threats to the future vitality of the ingroup shape intergroup emotion. In H. Wayment \& J. Bauer (Eds), Transcending self-interest: Psychological explorations of the quiet ego (pp. 171-181). Washington: American Psychological Association.

Wohl, M. J. A., \& Branscombe, N. R. (2006). Forgiving the ingroup or the outgroup for harm doing. In M. Bullock (Ed.) Forgiveness: A sampling of research results (p. 21-23). New York: United Nations.

Wohl, M. J. A., \& Branscombe, N. R. (2004). Importance of social categorization for forgiveness and collective guilt assignment for the Holocaust. In N. R. Branscombe \& B. Dooje (Eds.) Collective guilt: International perspectives (pp. 284-305). Cambridge University Press.

Wohl, M. J. A., \& Reeder, G. D. (2004). When bad deeds are forgiven: Judgments of morality and forgiveness for intergroup aggression. In J. P. Morgan (Ed.), Focus on aggression research (pp. 59-74). New York: Nova Science Publishers, Inc.

\section{Articles in refereed journals (171)}

Azevedo, F., Pavlović, T., Rêgo, G. G. d., Ay, F. C., Gjoneska, B., Etienne, T., ... Sampaio, W. M. (accepted). Social and moral psychology of COVID-19 across 69 countries. Nature Scientific Data.

Hollingshead, S. J. \& Wohl, M. J. A. (accepted). Leveraging loyalty programs for harm minimization: The lure of rewards increases willingness to use responsible gambling tools and attitudinal loyalty. International Journal of Mental Health and Addiction.

Hollingshead, S. J., Davis, C. G., \& Wohl, M. J. A. (in press). The customer-brand relationship in the gambling industry: Positive play predicts attitudinal and behavioural loyalty. International Gambling Studies. https://doi.org/10.1080/14459795.2022.2086992

Orazani, S. N., Wohl, M. J. A., \& Leidner, B. (in press). Third parties are supportive of social movement's use of violence when it previously used nonviolence (but failed to achieve change). Peace and Conflict StudiesL Journal of Peace Psychology. https://doi.org/10.1037/pac0000654 
Price, A., Tabri, N., Stark, S., Balodis, I., \& Wohl, M. J. A. (in press). Mental health over time and financial concerns predict change in online gambling during COVID-19. International Journal of Mental Health and Addiction. https://doi.org/10.1007/s11469-021-00750-5

St-Jean, R., Stefaniak, A., Salmon, M. M., Tabri, N., Wood, R. T. A., \& Wohl, M. J. A. (in press). The Cannabis Lower-Risk Scale: Psychometric validation of a multidimensional measure of lower-risk cannabis beliefs and behaviours. International Journal of Mental Health and Addiction. https://doi.org/10.1007/s11469022-00925-8

Wohl, M. J. A., Davis, C. G., \& Tabri, N. (in press). Setting a hard (versus soft) monetary limit decrease expenditure: An assessment using player account data. International Gambling Studies.

Ellis, E. D., Lister, J. J., Wohl, M. J. A., Greenwald, M. K., \& Ledgerwood, D. M. (2023). Exploring potential moderators of depressive symptoms and treatment outcomes among patients with opioid use disorder Addictive Behaviors, 140, 107604. https://doi.org/10.1016/j.addbeh.2022.107604

Kim, H. S., Coelho, S., Wohl, M. J. A., Rockloff, M., McGrath, D. S., \& Hodgins, D. C. (2023). Self generated motives of social casino gamers. Journal of Gambling Studies, 39, 299-320. https://doi.org/10.1007/s10899-022-10135-5

McLamore, Q., Syropoulos, S., Leidner, B., Hirschberger, G., van Bezouw, M., Paola Paladino, M., Rovenpor, D. et al. (2023). The distinct associations of ingroup attachment and glorification with responses to the coronavirus pandemic: Evidence from a multilevel investigation in 21 countries. British Journal of Social Psychology, 62, 992-1012. https://doi.org/10.1111/bjso.12614

Tabri, N., Salmon, M. M., \& Wohl, M. J. A. (2023). Advancing the Pathways Model: Financially focused self concept and erroneous beliefs as core psychopathologies in disordered gambling. Journal of Gambling Studies, 39, 13-31. https://doi.org/10.1007/s10899-022-10105-x

Tabri, N. \& Wohl, M. J. A. (2023). There is (still) a global factor that underlies the PGSI: A reanalysis of Tseng, Flack, Caudwell, and Stevens (2022). Addictive Behaviors, 140, 107623. https://doi.org/10.1016/j.addbeh.2023.107623

Wohl, M. J. A., Stefaniak, A., \& Smeekes, A. (2023). Collective nostalgia as a balm for the distressed social identity. Current Opinions in Psychology, 49, 101542. https://doi.org/10.1016/j.copsyc.2022.101542

Celikkol, G., Renvik, T. A., Sortheix, F., Jasinskaja-Lahti, I., Jetten J., et al (2022). Individual, group, and temporal perspectives on the link between wealth. Current Research in Ecological and Social Psychology, 3, 100054. https://doi.org/10.1016/j.cresp.2022.100054

Chayinska, M., Kende, A., \& Wohl, M. J. A. (2022). National identity and beliefs about historical linguicide are associated with support for exclusive language policies among the Ukrainian linguistic majority. Group Processes \& Intergroup Relations, 25, 924-940. https://doi.org/10.1177/1368430220985911

Clark, L. \& Wohl, M. J. A. (2022). Langer's illusion of control and the cognitive model of disordered Gambling. Addiction, 117, 1146-1151. https://doi.org/10.1111/add.15649

Kachanoff, F., Gray, K., Koestner, R., Kteily, N. \& Wohl, M. J. A. (2022). Collective autonomy: Why groups fight for power and status. Social and Personality Psychology Compass, 16, e12652. https://doi.org/10.1111/spc3.12652

McLamore, Q., Syropoulos, S., Leidner, B., Hirschberger, G., Young, K., Zein, R., et al. (2022). Trust in Scientific Information Mediates Associations between Conservatism and Coronavirus Responses in the U.S., but Few Other Nations. Nature Scientific Reports, 12, 3724. 
https://doi.org/10.1038/s41598-022-07508-6

Mutti-Packer, S., Kim, H. S., McGrath, D. S., Ritchie, E. V., Wohl, M. J. A., Rockloff, M., \& Hodgins, D. C., (2022). An experimental examination of the perceived responsible gambling efficacy of fear appeals in an online roulette platform, 22, 480-498. International Gambling Studies.

https://doi.org/10.1080/14459795.2022.2038655

Pavlović, T., Azevedo, F., De, K., Riaño-Moreno, J. C., Maglić, M., Gkinopoulos, T., Donnelly-Kehoe, P. A., Payán Gómez, C., Huang, G., Kantorowicz, J., Birtel, M. D., Schönegger, P., Capraro, V., Santamaría-García, H., Yucel, M., Ibanez, A., Rathje, S., Wetter, E., Stanojević, D., van Prooijen, J-W., Hesse, E. ... Van Bavel, J. J. (2022). Predicting attitudinal and behavioral responses to COVID-19 pandemic using machine learning. PNAS Nexus, 1(3), pgac093. https://doi.org/10.1093/pnasnexus/pgac093

Philander, K., Tabri, N., Wood, R. T. A, \& Wohl, M. J. A. (2022). Local impacts from casino access: Travel time and gambling problems. International Gambling Studies, 22, 459-479. https://doi.org/10.1080/14459795.2022.2035423

Stefaniak, A., \& Wohl, M. J. A. (2022). In time we will simply disappear: Racial demographic shift induces collective angst among high-power groups and intentions to preserve the intergroup hierarchy. Group Processes and Intergroup Relations, 25, NP1-NP23. https://doi.org/10.1177/13684302211023551

Stefaniak, A., Wohl, M. J. A., Blais, J., \& Pruysers, S. (2022). The I in us: personality influences the expression of collective nostalgia. Personality and Individual Differences, 187, 111392. https://doi.org/10.1016/j.paid.2021.111392

Stefaniak, A., Wohl, M. J. A., Bilewicz, M., \& Petelewicz, J. (2022). Leveraging knowledge about historical diversity: A meta-analysis of findings from the School of Dialogue intergroup intervention. Peace and Conflict Studies: Journal of Peace Psychology, 28(3), 314-326. https://doi.org/10.1037/pac0000626

Stefaniak, A., Wohl, M. J. A., \& Elgar, F. J. (2022). Commentary on "Different roles of interpersonal trust and institutional trust in COVID-19 pandemic control". Social Science \& Medicine, 299, 114765. https://doi.org/10.1016/j.socscimed.2022.114765

St-Jean R., Dowson, M. E., Stefaniak, A., Salmon, M. M., Tabri, N, Wood, R. T. A., \& Wohl, M. J. A. (2022). Understanding responsible cannabis consumption from the consumers' perspective: A rapid evidence assessment. Substance Use \& Misuse, 57, 1997-2007. https://doi.org/10.1080/10826084.2022.2129996

Tabri, N., Cheng, T., Palmer, L., Kim, H. S., Clark, L., \& M. J. A. Wohl (2022). Testing the bifactor model of financially focused self-concept. Journal of Gambling Issues, 50, 177-184. https://doi.org/10.4309/LZCW4190

Tabri, N. \& Wohl, M. J. A. (2022). Explaining reinforcement and erroneous beliefs in pathological exercise: A commentary and expansion on Coniglio using the Pathways Model of Disordered Gambling. International Journal of Eating Disorders, 55, 180-183. https://doi.org/10.1002/eat.23646

Van Bavel, J. J., Cichocka, A., Capraro, V., Sjåstad, H., Nezlek, J. B., Pavlović, T., Alfano, M., Gelfand, M. J., Azevedo, F., Birtel, M. D., Cislak, A., Lockwood, P. L., Ross, R. M., Stoyanova, K. K., Boggio, P. S., ... Zwaan, R. A. (2022). National identity predicts public health support during a global pandemic. Nature Communications, 13, 517. https://doi.org/10.1038/s41467-021-27668-9

Hollingshead, S. J., Kim, H. S., Rockloff, M., McGrath, D. S., Hodgins, D. C., \& Wohl, M. J. A. (2021). Motives for playing social casino games and the transition from gaming to gambling (or vice versa): social casino game play as harm reduction? Journal of Gambling Issues, 46, 43-61. https://doi.org/10.4309/jgi.2021.46.4 
Hollingshead, S. J., Wohl, M. J., \& Davis, C. G. (2021). On being loyal to a casino: The interactive influence of tier status and disordered gambling symptomatology on attitudinal and behavioral loyalty. Journal of Behavioral Addictions, 10, 675-682. https://doi.org/10.1556/2006.2021.00046

Kachanoff, F. J., Cooligan, F., Caouette, J., \& Wohl, M. J. A. (2021). Free to fly the rainbow flag: the relation between collective autonomy and psychological well-being amongst LGBTQ+ individuals. Self \& Identity, 20, 741-773. https://doi.org/10.1080/15298868.2020.1768890

Kim, H. S., Rockloff, M., Leslie, D., McGrath, D. S., Wohl, M. J. A., \& Hodgins, D. C. (2021). Offering small tangible rewards within social casino games increases in-play bets but does not impact real-money gambling. Addictive Behavior, 120, 106984. https://doi.org/10.1016/j.addbeh.2021.106984

Lima, M. E. O., de França, D. X., Jetten, J., Pereira, C. R., Wohl, M. J. A., Jasinskaja-Lahti, I., Hong, Y., Torres, A. R., Costa-Lopes, R., Ariyanto, A., Autin, F., Ayub, N., Badea, C., Besta, T., Butera, F., Fantini-Hauwel, C., Finchilescu, G., Gaertner, L., Gollwitzer, M., ... van der Bles, A. M. (2021). Materialist and post-materialist concerns and the wish for a strong leader in 27 countries. Journal of Social and Political Psychology, 9(1), 207-220. https://doi.org/10.5964/jspp.6213

Louderback, E. R., Wohl, M. J. A., \& LaPlante, D. A. (2021). Integrating open science practices into recommendations for accepting gambling industry research funding. Addiction Research \& Theory, 29, 79-87. https://doi.org/10.1080/16066359.2020.1767774

Orazani, N., Tabri, N., Wohl, M. J. A., \& Leidner, B. (2021). Social movement strategy (nonviolent vs. violent) and the garnering of third-party support: A meta-analysis. European Journal of Social Psychology, 51, 645-658. https://doi.org/10.1002/ejsp.2722

Peetz, J., Wohl, M. J. A, \& Davydenko, M. (2021). The cost of incremental self-theories: People spend more money after forgiving the self for past overspending. Personality and Individual Differences, 179, 110902. https://doi.org/10.1016/j.paid.2021.110902

Peetz, J., Wohl, M. J. A, Wilson, A., \& Dawson, A. (2021). A chip off the (im)moral block? Lay beliefs about genetic heritability predicts whether family members' actions affect self-judgments. European Journal of Social Psychology, 51, 722-739. https://doi.org/10.1002/ejsp.2768

Stefaniak, A., Wohl, M. J. A., \& Bilewicz, M. (2021). Pro-diversity Intervention Improves Poles' Intergoup Attitudes by Increasing Collective Nostalgia for More Open Polish Society. Affective Science. https://doi.org/10.1007/s42761-021-00031-3

Stefaniak, A., Wohl, M. J. A., Smeekes, A., Sedikedies, C., \& Wildschut, T. (2021). Different pasts for different political folk: Political orientation predicts collective nostalgia content. Frontiers in Political Science, 3, 1-15. https://doi.org/10.3389/fpos.2021.633688

Tabri, N., Werner, K. M., Milyavskaya, M., \& Wohl, M. J. A. (2021). Perfectionism predicts disordered eating and gambling via focused self-concept, especially among those high in erroneous beliefs about their disordered behavior. Journal of Behavioral Addictions, 10, 524-533. https://doi.org/10.1556/2006.2021.00068

Tabri, N., Philander, K. S., Wood, R. T. A, \& Wohl, M. J. A. (2021). Temporal measurement invariance of the financially focused self-concept construct. Journal of Gambling Issues, 48, 219-224. https//doi.org/10.4309/jgi.2021.48.11

Tabri, N., Salmon, M. M., \& Wohl, M. J. A. (2021). Financially focused self-concept in disordered gambling: Comparisons between non-disordered and disordered gambling subtypes. Addiction Research \& Theory, 26, 18-29. https//doi.org/10.1080/16066359.2020.1714039

Tabri, N., \& Wohl, M. J. A. (2021) Financially focused self-concept in disordered gambling. Current Addiction 
Reports, 8, 57-63. https//doi.org/10.1007/s40429-021-00360-0

Xuereb, S., Kim, H. S., Clark, L., \& Wohl, M. J. A. (2021). Substitution behaviors among people who gamble during COVID-19 precipitated casino closures. International Gambling Studies, 21, 411-425. https://doi.org/10.1080/14459795.2021.1903062

Xuereb, S., Wohl, M. J. A., Stefaniak, A., \& Elgar, F. (2021). Social and economic determinants of support for a strong leader in democracies differ from non-democracies. Journal of Social and Political Psychology, 9, 334 -352. https//doi.org/10.5964/jspp.7235

Elgar, F. J., Stefaniak, A., \& Wohl, M. J. A. (2020). The trouble with trust: Time-series analysis of social capital, income inequality, and COVID-19 deaths in 84 countries. Social Science \& Medicine, 263, 113365 https//doi.org/10.1016/j.socscimed.2020.113365

Elgar, F. J., Stefaniak, A., \& Wohl, M. J. A. (2020) Response to Lindström (2020) on "The trouble with trust: Time series analysis of social capital, income inequality, and COVID-19 deaths in 84 countries". Social Science \& Medicine, 265, 113518. https//doi.org/10.1016/j.socscimed.2020.113518.

Hornsey, M. J., Wohl, M. J. A., Harris, E. A., Okimoto, T. G.,Thai, M., \& Wenzel, M. (2020). Embodied remorse: Physical displays of remorse increase positive responses to public apologies, but have negligible effects on forgiveness. Journal of Personality and Social Psychology, 119, 367-389. https//doi.org /10.1037/pspi0000208

Kachanoff, F. J., Wohl, M. J. A., Koestner, R., \& Taylor, D. M. (2020). Them, us, and I: How intergroup contexts impact basic psychological needs. Current Direction in Psychological Science, 29, 47-54. https//doi.org/10.1177/0963721419884318

Orazani, S. N., Wohl, M. J. A., \& Leidner, B. (2020). Perceived normalization of radical ideologies and its effect on political tolerance and support for freedom of speech. Group Processes \& Intergroup Relations, 23, 1150-1170. https//doi.org/10.1177/1368430220943265

Salmon, M. M., \& Wohl, M. J. (2020). Longing for the past and longing for the future: A phenomenological assessment of the relation between temporal focus and readiness to change among people living with addiction. Frontiers in Psychology, 11, 1794. https//doi.org/10.3389/fpsyg.2020.01794

Stefaniak, A., Mallett, R. K., \& Wohl, M. J. A. (2020). Zero-sum beliefs shape advantaged allies' support for collective action. European Journal of Social Psychology, 50, 1259-1275. https//doi.org/10.1002/ejsp.2674

*Tabri, N., Wood, R. T. A., Philander, K., \& Wohl, M. J. A (2020). An examination of the validity and reliability of the Positive Play Scale: Findings from a Canadian national study. International Gambling Studies, 20, 282-295. https//doi.org/10.1080/14459795.2020.1732442

* Research of the Year Award, National Council on Problem Gambling

Van Bavel, J. J., Baicker, K., Boggio, P. S., Capraro, V., Cichocka, A., Cikara, M., Crockett, M. J., Crum, A. J., Douglas, K. M., Druckman, J. N. Drury, J., Dube, O., Ellemers, N., Finkel, E. J., Fowler, J. H., Gelfand, M., Han, S., Haslam, S. A., Jetten, J., Kitayama, S., Mobbs, D., Napper, L. E., Packer, D. J., Pennycook, G., Peters, E., Petty, R. E., Rand, D. G., Reicher, S. D., Schnall, S., Shariff, A., Skitka, L. J., Smith, S. S., Sunstein, C. R., Tabri, N., Tucker, J. A., van der Linden, S., Van Lange, P. A. M., Weeden, K. A., Wohl, M. J. A., Zaki, J., Zion, S. \& Willer, R. (2020). Using social and behavioural science to support COVID-19 pandemic response. Nature Human Behavior, 4, 460-471. https//doi.org/10.1038/s41562-020-0884-z

Wohl, M. J. A., Stefaniak, S., \& Smeekes, A. (2020). Days of future past: Concerns for the group's future prompts longing for its past (and ways to reclaim it). Current Direction in Psychological Science, 29, 481486. https//doi.org/10.1177/0963721420924766 
Wohl, M. J. A., Stefaniak, S., \& Smeekes, A. (2020). Longing is in the memory of the beholder:

Collective nostalgia content determines the method members will support to make their group great again. Journal of Experimental Social Psychology, 91, 104044. https//doi.org/10.1016/j.jesp.2020.104044

Hollingshead, S. J., Amar, M., Santesso, D., \& Wohl, M. J. A. (2019). When should players be taught to gamble responsibly? Timing of educational information alters limit setting intentions. Addiction Research \& Theory, 27, 507-514. https//doi.org/10.1080/16066359.2018.1555818

Hollingshead, S. J., Wohl, M. J. A., \& Santesso, D. (2019). Do you read me? Including personalized behavioral feedback to pop-up messages does not enhance limit adherence among gamblers. Computers in Human Behavior, 94, 122-130. https//doi.org/10.1016/j.chb.2019.01.015

Kachanoff, F. J., Taylor, D. M., Caouette, J., Khullar, T. H., \& Wohl, M. J. A. (2019). The chains on all my people are the chains on me: Restrictions to collective autonomy undermine the personal autonomy and psychological well-being of group members. Journal of Personality and Social Psychology, 116, 141-165. https//doi.org/ $10.1037 /$ pspp0000177

Kim, H. S., Rockloff, M., McGrath, D., Wohl, M. J. A., Hodgins, D. C. (2019). Structural or dispositional? An experimental investigation of the experience of winning in social casino games (and Impulsivity) on subsequent gambling behaviors. Journal of Behavioral Addictions, 8, 479-488. https//doi.org/ 10.1556/2006.8.2019.48

Peetz, J. \& Wohl, M. J. A. (2019). Perceiving time through group-based glasses: Collective temporal orientation. British Journal of Social Psychology, 58, 609-629. https//doi.org/10.1111/bjso.12291

Porat, R., Tamir, M., Wohl, M. J. A., Gur, T, \& Halperin, E. (2019). Motivated emotion and the rally around the flag effect: Liberals are motivated to feel collective angst (like conservatives) when faced with existential threat. Cognition and Emotion, 33, 480-491. https//doi.org/10.1080/02699931.2018.146032

Sprong, S., Jetten, J., Wang, Z., Peters, K., Mols, F., Verkuyten, M., Bastian, B., Ariyanto, A., Autin, F., Ayub, N., Badea, C., Besta, T., Butera, F., Costa-Lopes, R., Cui, L., Fantini, C., Finchilescu, G., Gaertner, L., Gollwitzer, M., ... Wohl, M. J. A. (2019). "Our Country Needs a Strong Leader Right Now”: Economic Inequality Enhances the Wish for a Strong Leader. Psychological Science, 30, 1625-1637. https://doi.org/10.1177/0956797619875472

Tabri, N., Hollingshead, S. J., \& Wohl, M. J. A. (2019). A limit approaching pop-up message reduces gambling expenditures, except among players with a financially focused self-concept. International Gambling Studies, 19, 327-338. https//doi.org/10.1080/14459795.2019.1567806

Wohl, M. J. A., Tabri, N., Hollingshead, S. J., Dupuis, D. R., \& Caouette, J. (2019). Empathetic collective angst predicts perpetrator group members' support for the empowerment of the victimized group. Journal of Personality and Social Psychology, 117, 1083-1104. https//doi.org/10.1037/pspi0000176

Wohl, M. J. A., Tabri, N., \& Zelenski, J. M (2019). The need for open science practices and well-conducted replications in the field of gambling studies. International Gambling Studies, 19, 369-376. https//doi.org/10.1080/14459795.2019.1672769

Elgar, F. J., Canale, N., Wohl, M. J. A., Lenzi, M, \& Vienno, A. (2018). Relative deprivation and disordered gambling in youths. Journal of Epidemiology \& Community Health, 72, 589-594. https//doi.org/10.1136/jech-2017-209858

Hackel, L. M., Coppin, G., Wohl, M. J. A., \& Van Bavel, J. J. (2018). From groups to grits: Social identity shapes evaluations of food pleasantness. Journal of Experimental Social Psychology. 74, 270-280. https//doi.org/10.1016/j.jesp.2017.09.007 
Kim, H. S., Shifrin, A., Sztainert, T., \& Wohl, M. J. A. (2018). Placing your faith on the betting floor: Religiosity predicts disordered gambling via gambling fallacies. Journal of Behavioral Addiction, 7, 401-409. https//doi.org/10.1556/2006.7.2018.23

King, D. L., \& the Gambling Industry Response Consortium (2018). Comment on the global gaming industry's statement on ICD-11 gaming disorder: A corporate strategy to disregard harm and deflect social responsibility? Addiction, 113, 2145-2146. https//doi.org/10.1111/add.14388.

Salmon, M. Kim, H. S., \& Wohl, M. J. A. (2018). In the mindset for change: Self reported quit attempts are a product of discontinuity-induced nostalgia and incremental beliefs. Journal of Social and Clinical Psychology, 37, 405-430. https//doi.org/10.1521/jscp.2018.37.6.405

Smeekes, A, Jetten, J., Verkuyten, M, Wohl, M. J. A., ... van der Bles, A.-M. (2018). Regaining in-group continuity in times of anxiety about the group's future: A study on the role of collective nostalgia across 27 countries. Social Psychology, 49, 311-329. https://doi.org/10.1027/1864-9335/a000350.

Sztainert, T., Hay, R., Wohl, M. J. A., \& Abizaid, A. (2018). Hungry to gamble? Ghrelin as a predictor of persistent gambling in the face of loss. Biological Psychology, 139, 115-123. https//doi.org/10.1016/j.biopsycho.2018.10.011

Tabri, N., Wohl, M. J. A., \& Caouette, J. (2018). We will be harmed, it will be severe, and we can't prevent it: Threat appraisals predict collective angst (and its consequences). European Journal of Social Psychology, 48, 72-85. doi:10.1002/ejsp.2303

Tabri, N., Wohl, M. J. A., Wood, R. T. A., \& Philander, K. (2018). Financially focused self-concept is associated with etiological and maintenance factors of gambling disorder Among Non-Problem Gamblers. Journal of Gambling Issues, 39, 308-313. https//doi.org/10.4309/jgi.2018.39.12

Tabri, N., Werner, K., Milyavskaya, M., \& Wohl, M. J. A. (2018). When nothing but a win matters: Perfectionism predicts disordered gambling via financially focused self-concept. Journal of Gambling Issues, 38, 252-267. https//doi.org/10.4309/jgi.2018.38.13

Wohl, M. J. A. (2018). Loyalty programs in the gambling industry: Potentials for harm and possibilities for harm minimization. International Gambling Studies, 8, 495-511. https//doi.org/10.1080/14459795.2018.1480649

Wohl, M. J. A., Kim, H. S., Salmon, M., Santesso, D., Wildschut, T., \& Sedikides, C. (2018). Discontinuity-induced nostalgia improves the odds of a self-reported quit attempt among people living with addiction. Journal of Experimental Social Psychology, 75, 83-94. https//doi.org/10.1016/j.jesp.2017.11.011

Hornsey, M. J., Bain, P. G., Blumen, S., Chen, S. X., Gómez, Á., González, R., Guan, Y., Kashima, E., Lebedeva, N., \& Wohl, M. J. A. (2017). Conservatives are more reluctant to give and receive apologies than liberals. Social Psychology and Personality Science, 8, 827-835. https//doi.org/10.1177/1948550617691096

Kachanoff, F. J., Caouette, J., Wohl, M. J. A., \& Taylor, D. M. (2017). Allowing the victim to draw a line in history: Intergroup apology effectiveness as a function of collective autonomy support. European Journal of Social Psychology, 47, 663-676. https//doi.org/10.1002/ejsp.2260

Kim, H. S., Hollingshead, S. J., \& Wohl, M. J. A. (2017). Who spends money to play for free? Identifying who makes micro-transactions on social casino games (and why). Journal of Gambling Studies, 33, 525-538. https//doi.org/10.1007/s10899-016-9626-6

Kim, H. S., Wohl, M. J. A., Gupta, R., \& Derevensky, J. (2017). Why do young adults gamble online? A qualitative study of motivations to transition from social casino games to online gambling. Asian Journal of Gambling Issues and Public Health, 7, 6. https//doi.org/10.1186/s40405-017-0025-4 
Kim, H. S., Wohl, M. J. A., Salmon, M. \& Santesso, D. (2017). When do problem gamblers help themselves? Self discontinuity increases self-directed change over time. Addictive Behavior, 64, 148-153. https//doi.org/10.1016/j.addbeh.2016.08.037

Tabri, N., Shead, W. N., \& Wohl, M. J. A., (2017). Me, myself, and money II: Relative deprivation predicts disordered gambling severity via delay discounting, especially among Gamblers who have a financially focused selfconcept. Journal of Gambling Studies, 33, 1201-1211. https//doi.org/10.1007/s10899-017-9673-7

Tabri, N., Wohl, M. J. A., Eddy, K. T., \& Thomas, J. J. (2017). Me, myself, and money: Having a financially focused self-concept and its consequences for disordered gambling. International Gambling Studies, 17, 30-50. https//doi.org/10.1080/14459795.2016.1252414

Wohl, M. J. A., \& Davis, C. G. (2017). Finding some straw in the 'Industry-State Gambling Complex' argument: Commentary on Delfabbro \& King (2017). International Gambling Studies, 17, 335-339. https//doi.org/10.1080/14459795.2017.1312483

Wohl, M. J. A., Davis, C. G., \& Hollingshead, S. J. (2017). How much have you won or lost? Personalized behavioral feedback about gambling expenditures regulates play. Computers in Human Behavior, 70, 437-445. https//doi.org/10.1016/j.chb.2017.01.025

Wohl, M. J. A., Salmon, M., Hollingshead, S. J., \& Kim, H. S. (2017). An examination of the relationship between social casino gaming and gambling: The bad, the ugly, and the potentially good. Journal of Gambling Issues, 35, 1-23. https//doi.org/10.4309/jgi.2017.35.4

Wood, R. T. A., Wohl, M. J. A., Tabri, N., \& Philander, K. (2017). Measuring responsible gambling amongst consumers: Development of the Positive Play Scale. Frontiers in Psychology, 8, 227-239. https//doi.org/10.3389/fpsyg.2017.00227

Dupuis, D., Wohl, M. J. A., Packer, D., \& Tabri, N. (2016). To dissent and protect: Stronger collective identification increases willingness to dissent when group norms evoke collective angst. Group Processes and Intergroup Relations, 19, 694-710. https//doi.org/10.1177/1368430216638535

Hollingshead, S. J., Kim, H. S., Wohl, M. J. A., \& Derevensky, J. (2016). The social casino gaming- gambling link: Motivation for playing social casino games determines whether self-reported gambling increases or decreases among disordered gamblers. Journal of Gambling Issues, 33, 52-67. https//doi.org/10.4309/jgi.2016.33.4

Kim, H. S., Salmon, M., Wohl, M. J. A., \& Young, M. (2016). A dangerous cocktail: Alcohol consumption increases suicidal ideations among problem gamblers in the general population. Addictive Behaviors, 55, 50-55. https//doi.org/10.1016/j.addbeh.2015.12.017

Kim, H. S., Wohl, M. J. A., Gupta, R., \& Derevensky, J. (2016). From the mouth of social media users: A focus group study exploring the social casino gaming - online gambling link. Journal of Behavioral Addiction, 5, 115-121. https//doi.org/10.1556/2006.5.2016.014

Lister, J. J., Nower, L., \& Wohl, M. J. A., (2016). Gambling goals predict chasing behavior during slot machine play. Addictive Behavior, 62, 129-134. https//doi.org/10.1016/j.addbeh.2016.06.018

Teymoori, A., Jetten, J., Bastian, B., Ariyanto, A., Autin, F., Ayub, N., Badea, C., Besta, T., Butera, F., Costa-Lopes, R., Cui, L., Fantini, C., Finchilescu, G., Gaertner, L., Gollwitzer, M., Gómez, Á., González, R., Hong, Y. Y., Jensen, D. H., ... Wohl, M. (2016). Revisiting the Measurement of Anomie. PloS One, 11, e0158370e0158370. https://doi.org/10.1371/journal.pone.0158370

Wohl, M. J. A., Porat, R., \& Halperin, E. (2016). Unfreezing cognitions during an intractable conflict: Does an external incentive for negotiating peace and (low levels of) collective angst increase information seeking? British 
Journal of Social Psychology, 55, 65-87. https//doi.org/10.1111/bjso.12121

Wohl, M. J. A. \& Tabri, N. (2016). The rocky road to reconciliation: Regulating emotions in an intergroup context. Psychological Inquiry, 27, 144-149. https//doi.org/10.1080/1047840X.2016.1153947

Xiao, Y. J., Wohl, M. J. A., \& Van Bavel, J. J. (2016). Proximity under threat: The role of physical distance in intergroup relations. PLoS ONE, 11, e0159792. https//doi.org/10.1371/journal.pone.0159792

Barlow, F. K., Thai, M., Wohl, M. J. A., White, S., Wright, M. A., \& Hornsey, M. J. (2015). Perpetrator groups can enhance their moral self-image by accepting their own intergroup apologies. Journal of Experimental Social Psychology, 60, 39-50. https//doi.org/10.1016/j.jesp.2015.05.001

Berndsen, M., Hornsey, M. J., \& Wohl, M. J. A. (2015). The impact of a victim-focused apology on forgiveness in an intergroup context. Group Processes and Intergroup Relations, 18, 726-739. https//doi.org/10.1177/1368430215586275

Hornsey, M.J., Wohl, M.J.A., \& Philpot, C.R. (2015). Collective apologies and their effects on forgiveness: Pessimistic evidence but constructive implications. Australian Psychologist, 50, 106-114. https//doi.org/10.1111/ap.12087

Kim, H. S., \& Wohl, M. J. A. (2015). The Bright Side of Self-Discontinuity: Feeling Disconnected With the Past Self Increases Readiness to Change Addictive Behaviors (via Nostalgia). Social Psychological \& Personality Science, 6, 229-237. https://doi.org/10.1177/1948550614549482

Kim, H. S., Wohl, M. J. A., Salmon, M. M., Gupta, R., \& Derevensky, J. (2015). Do social casino gamers migrate to online gambling? An assessment of migration rate and potential predictors. Journal of Gambling Studies, 31, 1819-1831. https//doi.org/10.1007/s10899-014-9511-0

Lister, J. J., Wohl, M. J. A., \& Davis, G. C. (2015). The dark side of authenticity: Feeling "real" while gambling interacts with enhancement motives to predict problematic gambling behavior. Journal of Gambling Studies, 31, 995-1003. https//doi.org/10.1007/s10899-014-9460-7

Salmon, M. M., Wohl, M. J. A., Sztainert, T., \& Kim, H. S. (2015). Potential clinical applications of responsible gambling tools. Canadian Journal of Addiction, 6, 72-77. http://dx.doi.org/10.1097/02024458-20150900000010

Tabri, N., Dupuis, D. R., Kim, H. S., \& Wohl, M. J. A. (2015). Economic mobility moderates the effect of relative deprivation on financial gambling motives and disordered gambling. International Gambling Studies, 15, 309323. https//doi.org/10.1080/14459795.2015.1046468

Wohl, M. J. A., Cohen-Chen, S., Halperin, E., Caouette, J., Hayes, N., \& Hornsey, M. J. (2015). Belief in the malleability of groups strengthens the tenuous link between a collective apology and intergroup forgiveness. Personality and Social Psychology Bulletin, 41, 714-725. https//doi.org/10.1177/0146167215576721

Wohl, M. J. A. \& Wood, R. (2015). Is gambling industry-funded research necessarily a conflict of interest? A Reply to Cassidy (2014). International Gambling Studies, 15, 12-14. https//doi.org/10.1080/14459795.2014.997270

Wood, R. \& Wohl, M. J. A. (2015). Assessing the effectiveness of a responsible gambling focused behavioural feedback tool for reducing the gambling expenditure of at-risk players. International Gambling Studies, 15, 324-339. https//doi.org/10.1080/14459795.2015.1049191

Kim, H., Wohl, M. J. A., Stewart, M., Sztainert, T., \& Gainsbury, S. (2014). Limit your time, gamble responsibility: Setting a time limit (via pop-up message) on an electronic gambling machine reduces time on device. International Gambling Studies, 14, 266-278. https//doi.org/10.1080/14459795.2014.910244

Sztainert, T., Wohl, M. J. A., McManus, J. F., \& Stead, J. D. (2014). On being attracted to the possibility of a win: 
Reward sensitivity (via gambling motives) undermines treatment seeking among pathological gamblers. Journal of Gambling Studies, 30, 901-911. https//doi.org/10.1007/s10899-013-9394-5

Stzainert, T., Kim, H. S., \& Wohl, M. J. A. (2014). Knowledge translation and exchange in gambling research: A beginners guide. Responsible Gambling Review, 1, 64-74.

Warner, R. H., Wohl, M. J. A., \& Branscombe, N. R. (2014). When do victim group members feel a moral obligation to help suffering others? European Journal of Social Psychology, 44, 231-241. https//doi.org/10.1002/ejsp.2010.

Wohl, M. J. A., Branscombe, N. R., \& Lister, J. J. (2014). When the going gets tough: Economic threat increases financial risk taking in games of chance. Social Psychology and Personality Science, 5, 211-217. https//doi.org/10.1177/1948550613490964

Wohl, M. J. A., Kim, H. S., \& Sztainert, T. (2014). From the laboratory to the casino: Using psychological principles to design better responsible gambling tools. Responsible Gambling Review, 1, 16-26.

Wohl, M. J. A., King, M., \& Taylor, D. M. (2014). Expressions of political practice: Collective angst moderates politicized collective identity to predict support for political protest (peaceful or violent) among diaspora group members. International Journal of Intercultural Relations, 43,114-125. https//doi.org/10.1016/j.ijintrel.2014.08.020

Wohl, M. J. A., \& McLaughlin, K. L. (2014). Self-forgiveness: The good, the bad, and the ugly. Social and Personality Psychology Compass, 8, 422-435. https//doi.org/10.1111/spc3.12119

Wohl, M. J. A., Parush, A., Kim, H. S., \& Warren, K. (2014). Building it better: Applying Human Computer Interaction and Persuasive System Design Principles to a monetary limit tool improves responsible gambling. Computers in Human Behavior, 37, 124-132. https//doi.org/10.1016/j.chb.2014.04.045

Halperin, E., Porat, R., \& Wohl, M. J. A. (2013). Extinction threat and reciprocal threat reduction: Collective angst predicts willingness to compromise in intractable intergroup conflicts. Group Processes and Intergroup Relations, 16, 797-813. https//doi.org/10.1177/1368430213485994

Hornsey, M. J. \& Wohl, M. J. A. (2013). We are sorry: Intergroup apologies and their tenuous link with intergroup forgiveness. European Review of Social Psychology, 24, 1-31. https//doi.org/10.1080/10463283.2013.822206

Stewart, M. J. \& Wohl, M. J. A. (2013). Pop-up messages, dissociation, and craving: How monetary limit reminders facilitate adherence in a session of slot machine gambling. Psychology of Addictive Behavior, 27, 288-273. https//doi.org/10.1037/a0029882

Imhoff, R., Wohl, M. J. A., \& Erb, H.-P. (2013). When the past is far from dead: How ongoing consequences of genocides committed by the ingroup impact collective guilt. Journal of Social Issues, 69, 74-91. https//doi.org/10.1111/josi.12004

Wohl, M. J. A., Gainsbury, S., Stewart, M. J., \& Sztainert, T. (2013). Facilitating responsible gambling: The relative effectiveness of education-based animation and monetary limit setting pop-up messages among electronic gaming machine players. Journal of Gambling Studies, 29, 703-717. https//doi.org/10.1007/s10899-012-9340-y

Wohl, M. J., Matheson, K., Branscombe, N. R., \& Anisman, H. (2013). Victim and perpetrator groups' responses to the Canadian government's apology for the head tax on Chinese immigrants and the moderating influence of collective guilt. Political Psychology, 34, 713-729. https//doi.org/10.1111/pops.12017

Wohl, M. J. A., Santesso, D. L., \& Harrigan, K. (2013). Reducing erroneous cognition and the frequency of exceeding limits among slots players: A short (3-minute) educational animation facilitates responsible gambling. International Journal of Addiction and Mental Health, 11, 409-423. 
https//doi.org/10.1007/s11469-012-9424-z

Jetten, J., \& Wohl, M. J. A. (2012). The past as a determinant of the present: Historical continuity, collective angst, and opposition to immigration. European Journal of Social Psychology, 42, 442-450.

https//doi.org/10.1002/ejsp.865

Caouette, J., Wohl, M. J. A., \& Peetz, J. (2012). The future weighs heavier than the past: Collective guilt, perceived control and the influence of time. European Journal of Social Psychology, 42, 363-371.

https//doi.org/10.1002/ejsp.185

Davis, C. G., Harasymchuk, C. \& Wohl, M. J. A. (2012). Finding meaning in a traumatic loss: A families approach. Journal of Traumatic Stress, 25, 142-149. https//doi.org/10.1002/jts.21675

Greenaway, K. Louis, W., \& Wohl, M. J. A. (2012). Awareness of common humanity reduces empathy and heightens expectations of forgiveness for temporally distant wrongdoing. Social Psychology and Personality Science, 3, 446-454. https//doi.org/10.1177/1948550611425861.

McCarrey, A. C., Henry, J. D., von Hippel, B., Weidemann, G., Sachdev, P. S., Wohl, M. J. A., \& Williams, M. (2012). Age differences in neural activation during slot machine gambling: An fMRI study. PLoS ONE, 7, e49787. https//doi.org/10.1371/journal.pone.0049787

Squires, E., Sztainert, T., Gillen, N., Caouette, J., \& Wohl, M. J. A. (2012). The problem with self-forgiveness: Forgiving the self deters readiness to change in gamblers. Journal of Gambling Studies, 28, 337-350. https//doi.org/10.1007/s10899-011-9272-y.

Wohl, M. J. A., Hornsey, M. J., \& Bennett, S. H. (2012). Why group apologies succeed and fail: Intergroup forgiveness and the role of primary and secondary emotions. Journal of Personality and Social Psychology, 102, 306-322. https//doi.org/10.1037/a0024838.

Wohl, M. J. A., Squires, E. C, \& Caouette, J. (2012). We were, we are, will we be? The social psychology of collective angst. Social and Personality Psychology Compass, 6, 379-391. https//doi.org/10.1111/j.17519004.2012.00437.x

Ysseldyk, R., \& Wohl, M. J. A. (2012). I forgive therefore I'm committed: A longitudinal examination of commitment after a romantic relationship transgression. Canadian Journal of Behavioural Science, 44, 257-263. https//doi.org/10.1037/a0025463.

Elgar, F. J., Davis, C. G., Wohl, M. J. A, Trites, S. J., Zelenski, J. M., \& Martin, M. S. (2011). Social capital, health and life satisfaction in 50 countries. Health and Place, 17, 1044-1053. https//doi.org/10.1016/j.healthplace.2011.06.010.

Wohl, M. J. A., Hornsey, M. J., \& Philpot, C. R. (2011). A critical review of official public apologies: Aims, pitfalls, and a staircase model of effectiveness. Social Issues and Policy Review, 5, 70-100. https//doi.org/10.1111/j.1751-2409.2011.01026.x.

Wohl, M. J. A., \& Van Bavel, J. J. (2011). Is identifying with a historically victimized group good or bad for your health? Transgenerational post-traumatic stress and collective victimization. European Journal of Social Psychology, 41, 818-824. https://doi.org/10.1002/ejsp.844.

Wohl, M. J. A., Giguère, B., Branscombe, N. R., \& McVicar, D. N. (2011). One day we might be no more: Collective angst and protective action from potential distinctiveness loss. European Journal of Social Psychology, 41, 289-300. https//doi.org/10.1002/ejsp.773.

Wohl, M. J. A., Stewart, M. J., \& Young, M. M. (2011). Personal luck usage scale (PLUS): Psychometric validation of a measure of gambling-related belief in luck as a personal possession. International Gambling Studies, 11, 721. https//doi.org/10.1080/14459795.2010.541270. 
Wohl, M. J. A., \& Sztainert, T. (2011). Where did all the pathological gamblers go? Gambling symptomatology and stage of change predict attrition in longitudinal research. Journal of Gambling Studies, 27, 155-169. https//doi.org/10.1007/s10899-010-9186-0.

Wohl, M. J. A., \& Thompson, A. (2011). A dark side to self-forgiveness: Forgiving the self and its association with chronic unhealthy behaviour. British Journal of Social Psychology, 50, 354-364. https//doi.org/10.1111/j.2044-8309.2010.02010.x.

Young, M. M., \& Wohl, M. J. A. (2011). Canadian Problem Gambling Index: An evaluation of the scale and its accompanying profiler software in a clinical setting. Journal of Gambling Studies, 27, 467-485. https//doi.org/10.1007/s10899-010-9224-y.

Wohl, M.J.A., Branscombe, N.R., \& Reysen, S. (2010). Perceiving your group's future to be in jeopardy: Extinction threat induces collective angst and the desire to strengthen the ingroup. Personality and Social Psychology Bulletin, 36, 898-910. https//doi.org/10.1177/0146167210372505.

Wohl, M. J. A., Christie, K. L., Matheson, K., \& Anisman, H. (2010). Animation-based education as a gambling prevention tool: Correcting erroneous cognitions and reducing the frequency of exceeding limits among slots players. Journal of Gambling Studies, 26, 469-486. https//doi.org/10.1007/s10899-009-9155-7.

Wohl, M. J. A., Pychyl, T. A., \& Bennett, S. H. (2010). I forgive myself, now I can study: How self-forgiveness for procrastinating can reduce future procrastination. Personality and Individual Differences, 48, 803-808. https//doi.org/10.1016/j.paid.2010.01.029.

Matheson, K., Wohl, M. J. A., \& Anisman, H. (2009). The interplay of appraisals, specific coping styles, and depressive symptoms among young male and female gamblers. Social Psychology, 40, 212-221. https//doi.org/10.1027/1864-9335.40.4.212.

Young, M. M., \& Wohl, M. J. A. (2009). The gambling craving scale: Psychometric validation and behavioral implications. Psychology of Addictive Behaviors, 23, 512-522. https//doi.org/10.1037/a0015043.

Wohl, M. J. A., \& Branscombe, N. R. (2009). Group threat, collective angst and ingroup forgiveness for the war in Iraq. Political Psychology, 30, 193-217. https//doi.org/10.1111/j.1467-9221.2008.00688.x.

Wohl, M. J. A. \& Enzle, M. E. (2009). Illusion of control by proxy: Placing one's fate in the hands of another. British Journal of Social Psychology, 48, 183-200. https//doi.org/10.1348/014466607X258696.

Wohl, M. J. A., Lyon, M., Young, M. M., Donnelly, C., Matheson, K., \& Anisman, H. (2008). Episodic cessation of gambling: A numerically aided phenomenological analysis. International Gambling Studies, 8, 249-264. https//doi.org/10.1080/14459790802405855

Young, M. M., Wohl, M. J. A., Matheson, K., Bauman, S., \& Anisman, H. (2008). The desire to gamble: The influence of outcomes on the priming effects of a gambling episode. Journal of Gambling Studies, 24, 275-293. https//doi.org/10.1007/s10899-008-9093-9.

Brown, R. P., Wohl, M. J. A., \& Exline, J. J. (2008). Taking up offenses: Second-hand forgiveness and identification with targets of transgressions. Personality and Social Psychology Bulletin, 34, 1406-1419. https//doi.org/10.1177/0146167208321538.

Wohl, M. J. A., \& Branscombe, N. R. (2008). Remembering historical victimization: Collective guilt for current ingroup transgressions. Journal of Personality and Social Psychology, 94, 988-1006. https//doi.org/10.1037/0022-3514.94.6.988.

Wohl, M. J. A., DeShea, L., \& Wahkinney, R. L. (2008). Looking within: The state forgiveness scale. Canadian Journal of Behavioural Science, 40, 1-10. https//doi.org/10.1037/0008-400x.40.1.1.1. 
Wohl, M. J. A, Matheson, K., Young, M. M., \& Anisman, H. (2008). Morning cortisol elevations among problem gamblers: Dissociation from comorbid symptoms of depression and impulsivity. Journal of Gambling Studies, 24, 79-90. doi:10.1007/s10899-007-9080-6.

Wohl, M. J. A. (2008). Belief in a lucky self: The role of personal luck in the facilitation and maintenance of gambling behavior. Psychologie Francaise, 53, 7-23. https//doi.org/10.1016/j.psfr.2006.08.004

Davis, C. G., Wohl, M. J. A., \& Verberg, N. (2007). Profiles of posttraumatic growth following an unjust loss. Death Studies, 31, 693-712. https//doi.org/10.1080/07481180701490578.

Wohl, M. J. A., \& McGrath, A. L. (2007). The perception of time heals all wounds: Temporal distance affects willingness to forgive following an interpersonal transgression. Personality and Social Psychology Bulletin, 33, 1023-1035. https//doi.org/10.1177/0146167207301021.

Wohl, M. J. A., Young, M. M., \& Hart, K. E. (2007). Self-perceptions of dispositional luck: Relationship to DSM gambling symptoms, subjective enjoyment of gambling and treatment readiness. Substance Use \& Misuse. 42, 43-63. https//doi.org/10.1080/10826080601094223

Schimel, J., Wohl, M. J. A., \& Williams, T. (2006). Terror management and trait empathy: Evidence that mortality salience promotes reactions of forgiveness among people with high (vs. low) trait empathy. Motivation and Emotion, 30, 217-227. https//doi.org/10.1007/s11031-006-9040-y.

Wohl, M. J. A., Branscombe, N. R., \& Klar, Y. (2006). Collective guilt: An emotional response to perceived ingroup misdeeds. European Review of Social Psychology, 17, 1-37. https//doi.org/10.1080/10463280600574815.

Wohl, M. J. A., Kuiken, D., \& Noels, K. A. (2006). Three ways to forgive: A numerically aided phenomenological study. British Journal of Social Psychology, 45, 547-561. https//doi.org/10.1348/014466605X53695.

Reeder, G. D., Pryor, J. B., Wohl, M. J. A., \& Griswell, M. L. (2005). On attributing negative motives to others who disagree with our opinions. Personality and Social Psychology Bulletin, 31, 1498-1510. https//doi.org/10.1177/0146167205277093.

Wohl, M. J. A., \& Branscombe, N. R. (2005). Forgiveness and collective guilt assignment to historical perpetrator groups depend on level of social category inclusiveness. Journal of Personality and Social Psychology, 88, 288-303. https//doi.org/10.1037/0022-3514.88.2.288

Wohl, M. J. A., Young, M. M., \& Hart, K. E. (2005). Untreated young gamblers with game-specific problems: Self concept involving luck, gambling ecology and delay in seeking professional treatment. Addiction Research and Theory, 13, 445-459. https//doi.org/10.1080/16066350500168444.

Branscombe, N. R., Wohl, M. J. A., Owen, S., Allison, J. A., \& N'gbala, A. (2003). Counterfactual thinking, blame, and well-being among rape victims. Basic and Applied Social Psychology, 25, 265-273.

https//doi.org/:10.1207/S15324834BASP2504_1.

Wohl, M. J. A., \& Enzle, M. E. (2003). The effects of near wins and losses on self-perceived personal luck and subsequent gambling behavior. Journal of Experimental Social Psychology, 39, 184-191. https//doi.org/10.1016/S0022-1031(02)00525-5.

Enzle, M. E., \& Wohl, M. J. A. (2002). Manipulating personal salience, redux: An occasion for recalling the problem with the correlational approach. Representative Research in Social Psychology, 26, 15-25.

Wohl, M. J. A., \& Enzle, M. E. (2002). The deployment of personal luck: Illusory control in games of pure chance. Personality and Social Psychology Bulletin, 28, 1388-1397. https//doi.org/10.1177/014616702236870.

Wohl, M. J. A., Pritchard, E. T., \& Kelly, B. (2002). How responsible are people for their employment situation? An application of the triangle model of responsibility. Canadian Journal of Behavioural Science, 34, 3, 201-209. https//doi.org/10.1037/h0087172. 


\section{Government or technical reports (41)}

St-Jean, R., Dowson, M. E., Stefanaik, A., Salmon, M. M., Tabri, N, Wood, R. T. A., \& Wohl, M. J. A. (2022). How do people who use cannabis understand responsible use? A rapid evidence assessment. [Research Report]. Ottawa, ON: Canadian Centre on Substance Use and Addiction.

Tabri, N., Wohl, M. J. A., \& Xuereb, S. (2020). Population-based safer gambling/responsible gambling efforts [Report]. Guelph, ON: Gambling Research Exchange Ontario.

Wood, R., Tabri, N., \& Wohl, M. J. A. (2019). Measuring responsible gambling with Skybetting and gambling customers [Report]. Leeds, UK: Sky Betting and Gaming.

Wohl, M. J. A. \& Davis, G. D. (2020). My PlaySmart evaluation at Rideau Carleton Raceway: Assessment of player self-reports at two time points. [Report]. Toronto, ON: Ministry of Health and Long-Term Care.

Wood, R., Tabri, N., \& Wohl, M. J. A. (2019). Measuring responsible gambling in the Minnesota [Report]. Roseville, MN: Minnesota Lottery.

Wood, R., Tabri, N., \& Wohl, M. J. A. (2019). Measuring responsible gambling in the New Jersey [Report]. Trenton, NJ: New Jersey Lottery.

Wood, R., Tabri, N., \& Wohl, M. J. A. (2019). Measuring responsible gambling in the New Zealand [Report]. Auckland, NZ: Lotto NZ.

Wood, R., Tabri, N., \& Wohl, M. J. A. (2019). Measuring responsible gambling in the UK [Report]. London: Camelot UK.

Wood, R., Tabri, N., \& Wohl, M. J. A. (2018). Messaging guidelines for improving gambling literacy among players in Nova Scotia who are 19-34 years-old. [Report]. Halifax, NS: Nova Scotia Gaming Corporation.

Wood, R., Tabri, N., \& Wohl, M. J. A. (2018). National validation of the Positive Play Scale: Assessing responsible gambling across Canada [Report]. Toronto, ON: Canadian Responsible Gambling Association.

Wohl, M. J. A. (2018). An assessment of coasters and its social responsibility [Report]. Dartmouth, N.S.: Atlantic Lottery Corporation.

Amar, M., Hollingshead, S. J., Santesso, D., \& Wohl, M. J. A. (2018). Facilitating limit setting and limit adherence. [Research Report]. Winnipeg, MB: Manitoba Gambling Research Program.

Kim, H. S, \& Wohl, M. J. A. (2017). Connections Therapy: An assessment of a new treatment program for disordered gamblers. Guelph, ON: Gambling Research Exchange Ontario

Salmon, M. M., Hollingshead, S. J., Paynter, A. A., Tabri., N., Goldstein, A., \& Wohl, M. J. A. (2017). Overcoming barriers to change via reflecting on the positive past: A rapid evidence assessment. [Report]. Guelph, ON: Gambling Research Exchange Ontario.

Wohl, M. J. A. (2017). Modifying the denomination limit on EGM-based bill acceptors: A critical review. [Report]. Halifax, NS: Nova Scotia Provincial Lotteries and Casino Corporation.

Wohl, M. J. A. (2017). Review of NSPLCC's responsible gambling casino training scenarios and script. [Report]. Halifax, NS: Nova Scotia Provincial Lotteries and Casino Corporation.

Wohl, M. J. A. (2017). Evidence exchange: Loyalty programs in the gambling industry. [Report]. Guelph, ON: Gambling Research Exchange Ontario.

Wohl, M. J. A. \& Davis, C. G. (2017). My PlaySmart: Georgian Downs Evaluation. [Report]. Toronto, ON: Ontario 
Lottery Corporation.

Wohl, M. J. A. (2016). The social responsibility of player rewards [Report]. Dartmouth, N.S.: Atlantic Lottery Corporation.

Wohl, M. J. A., Santesso, D., Kim, H. S., Salmon, M., Sedikides, C., \& Wildschut, T. (2016). Overcoming barriers to treatment. [Research Report]. Winnipeg, MB: Manitoba Gambling Research Program.

Wood, R. T. A., Wohl, M. J. A., \& Tabri, N. (2016). Defining and measuring responsible gambling behaviour: Developing the Positive Play Index. [Report]. Vancouver, BC: British Columbia Lottery Corporation.

Wohl, M. J. A., Salmon, M. M., \& Kim, H. S. (2015). Discontinuity and change among disordered gamblers. [Research Report]. Beverly, MA: National Center for Responsible Gaming.

Kim, H. S., Wohl, M. J. A., Gupta, R., \& Derevensky, J. (2014). Play-for-fun to play-for-pay: Identifying factors that transition people from social network gaming to online gambling [Research Report]. Guelph, ON: Ontario Problem Gambling Research Centre.

Stead, J., Wohl, M. J. A., Sztainert, T., Matheson, K., \& Anisman, H. (2014). Genetic analysis of the endophenotypes of impulsivity and reward dependence in pathological gambling [Research Report]. Guelph, ON: Ontario Problem Gambling Research Centre.

Wohl, M. J. A. (2014). Skilled Bonus at Red Shores Charlottetown: Risks and recommendations associated with inclusion of skilled bonus games on slot machines [Report]. Dartmouth, N.S.: Atlantic Lottery Corporation.

Wohl, M. J. A. (2013). Initial evaluation of AL's Player Services Vision: Possible effects of rewarding the player for using responsible gambling tools [Report]. Dartmouth, N.S.: Atlantic Lottery Corporation.

Parush, A. Wohl, M. J. A., Mitchell, K., \& Kim, H. (2013). Facilitating responsible gambling through persuasive technology: Using human-computer interaction principles to better money limit tools. [Research Report]. Guelph, ON: Ontario Problem Gambling Research Centre.

Santesso, D. L., Wohl, M. J. A., \& Harrigan, K. (2013). Assessment of a short educational animation in reducing erroneous cognitions and facilitating adherence to monetary limits among slot machine gamblers: A 30-day follow-up study [Research Report]. Guelph, ON: Ontario Problem Gambling Research Centre.

Wood, R. \& Wohl, M. J. A. (2013). Evaluating the effectiveness of Playscan as a tool to aid responsible gambling and minimise problematic gambling beahviours [Report]. Sundbyberg, Sweden: Svenska Spel.

Wohl, M. J. A. (2013). Initial evaluation of AL's Player Services Vision: Possible effects of rewarding the player for using responsible gambling tools [Report]. Dartmouth, N.S.: Atlantic Lottery Corporation.

Taylor, D. M., Wohl, M. J. A., King, M., \& Kawatra, L. (2012). The voice of young Somali Canadians: Identity, threat and the appeal of ANSA groups [Research Report]. Toronto, ON: Defence R\&D - Toronto.

Wohl, M. J. A. (2012). Assessing pre-commitment: Research ideas aimed at facilitating limit setting and adherence [Report]. Vancouver, BC: British Columbia Lottery Corporation.

Wohl, M. J. A. (2012). Issues review on pre-commitment [Report]. Vancouver, BC: British Columbia Lottery Corporation.

Wohl, M. J. A. (2012). Assessment of Nova Scotia Gaming Corporation's My-Play System Change Limit Option [Report]. Halifax, N.B.: Nova Scotia Gaming Corporation.

Wohl, M. J. A. (2012). Blackjack at Red Shores Charlottetown: An Assessment of the Risks Associated with Blackjack Play and Recommendations for Minimizing Those Risks [Report]. Dartmouth, N.S.: Atlantic Lottery Corporation. 
Wohl, M. J. A., \& Stewart, M. J. (2012). Promoting responsible gambling: Assessing the efficacy of initiatives aimed at increasing monetary and time limit adherence among slot machine gamblers [Research Report]. Guelph, ON: Ontario Problem Gambling Research Centre.

Wohl, M. J. A. \& Sztainert, T. (2012). Atlantic Lottery's proposed player service approach: Review, assessment, and recommendations [Report]. Dartmouth, N.S.: Atlantic Lottery Corporation.

Taylor, D. M., Wohl, M. J. A., King, M., Etemadi, P. (2011). The psychology of violent conflict in failing states. [Report]. Toronto, ON: Defence R\&D - Toronto.

Christie, K. L., Wohl, M. J. A., Matheson, K., \& Anisman, H. (2010). Appraisals and expectancies in relation to the evolution and cessation of gambling behaviours among young adults. [Research Report]. Guelph, ON: Ontario Problem Gambling Research Centre.

Wohl, M. J. A., Christie, K. L., Matheson, K., \& Anisman, H. (2009). Can animation-based education correct erroneous cognitions and reduce the frequency of exceeding limits among slots players? [Research Report]. Guelph, ON: Ontario Problem Gambling Research Centre.

Wohl, M. J. A., Anisman, H., Matheson, K., \& Young, M. M. (2006). Personal luck, outcome expectancies, and subjective appraisals as predictors of health and readiness to seek treatment among young adults. [Research Report]. Guelph, ON: Ontario Problem Gambling Research Centre.

\section{Journalistic writing (2)}

Packer, D. J. \& Wohl, M. J. A. (2017, July 20). Most Republicans still say they support Trump. Who's most likely to break ranks and speak out against him? [Editorial]. The Washington Post, retrieved from https:/www.washingtonpost.com/news/monkey-cage/wp/2017/07/20/most-republicans-still-say-they-supporttrump-whos-most-likely-to-break-ranks-and-speak-out-against-him/?utm term $=.98849 \mathrm{~b} 99252 \mathrm{f}$.

Wohl, M. J. A. (2012, December 16). The anxiety of group survival [Editorial]. The New York Times, p. SR12.

\section{Articles under review in refereed journals (6)}

Ruggeri, K., Stock, F., Haslam, S. A., Wohl, M. J. A. ..., Van Bavel, J. J., \& Willer, R. (revise and resubmit). Evaluating expectations from social and behavioral science about COVID-19 and lessons for the next pandemic. Nature.

Bradley, A. H. M, Salmon, M., Wohl, M. J. A., Howard, A. L. (under initial review). Impact of legalization on cannabis use, attitudes, and purchasing preferences: A panel study of Canadian young adults. Prevention Science.

Stefaniak, A., Wohl, M. J. A., \& Higgison, K. (under initial review). Men have changed: The valence of gender role discontinuity and collective nostalgia shape men's support for gender equality. Psychological Science.

Tabri, N., Hollingshead, S., \& Wohl, M. J. A. (under initial review). Framing COVID-19 as an existential threat predicts prejudice towards Chinese people via anxious arousal. Social and Personality Psychology Compass.

Wenzel, M., Quinney, B., Wohl, M. J. A., Barron, A., Woodyat, L. (under initial review). The tensions between collective-self forgiveness and political repair. Personality and Social Psychology Bulletin.

Wohl, M. J. A., Dowson, M. E., Salmon, M. M., Sedikides, C., \& Wildschut, T. (under initial review). The utility of nostalgia for unhealthy populations: A systematic review and narrative analysis. Health Psychology Review.

\section{Editorial Responsibilities}




\section{a) Associate editor}

British Journal of Social Psychology, Associate Editor, 2018-2019

Journal of Experimental Social Psychology, Associate Editor, 2016-2017

Basic and Applied Social Psychology, Associate Editor, 2011-2014

\section{b) Editorial board}

Journal of Gambling Issues, Consulting Editor, 2016-present

Basic and Applied Social Psychology, Consulting Editor, 2014-present

Personality and Social Psychology Bulletin, Consulting Editor, 2014-present

Responsible Gambling Review, Consulting Editor, 2014-present

International Gambling Studies, Consulting Editor, 2010-present

Social Psychology, Consulting Editor, 2007-present

Journal of Experimental Social Psychology, Associate Editor, 2017-2021

British Journal of Social Psychology, Consulting Editor, 2009-2018

European Journal of Social Psychology, Consulting Editor, 2012-2015

\section{Papers Presented}

\section{a) to learned societies}

Bossom, I. R. L., Dowson, M. E., Salmon, M. M., Tabri, N., Wohl, M. J. A. (2023, March). Missing the past eating disorder: Exploring the dark side of nostalgia during eating disorder recovery. Paper presented at the $19^{\text {th }}$ Annual Crossroads Interdisciplinary Health Research Conference, Halifax, Nova Scotia.

McLamore, Q., Syropoulos, S., Leidner, B., Hirschberger, G., Young, K., Zein, R. A., Baumert, A., Bilewicz, M., Bilgen, A., Burrows, B., Chatard, A., Chekroun, P., Chinchilla, J., Choi, H.-S., Euh, H., Gomez, A., Kardos, P., Khoo, Y. H., Li, M, Légal, J.-B., Loughnan, S., Mari, S., Tan-Mansukhani, R., Muldoon, O., Noor, M., Petrović, N., Selvanathan, H. P., Uluğ, Ö. M., Wohl, M. J., Yeung, W. L. V. (2022, February). Conservatism, trust in science, and coronavirus, in the U.S. and across the globe. Presented at the Society for Personality and Social Psychology (SPSP) conference, San Francisco, CA.

Syropoulos, S., McLamore, Q., Leidner, B, Hirschberger, G., van Bezouw, M. J., Rovenpor, D., Paladino, M. P., Baumert, A., Bilewicz, M., Bilgen, A., Chatard, A., Chekroun, P., Chinchilla, J., Choi, H.-S., Euh, H., Gomez, A., Kardos, P., Khoo, Y. H., Li, M/, Légal, J.-B., Loughnan, S., Mari, S., Tan-Mansukhani, R., Muldoon, O., Noor, M., Petrović, N., Selvanathan, H. P., Uluğ, Ö. M., Wohl, M. J., Yeung, W. L. V., Young, K., \& Zein, R. A. (2022, February). The divergent impact of ingroup attachment and glorification on responses to the coronavirus pandemic: Evidence from a multilevel investigation in 21 Countries. Presented at the Society for Personality and Social Psychology (SPSP) conference, San Francisco, CA.

Tabri., N., Kim, H. S., Clark, L., \& Wohl, M. J. A. (2021, November). Variations in sensation seeking, impulsivity, and financially focused self-concept predict an array of co-occurring addictive behaviour profiles. Poster presented at the Canadian Centre on Substance Use and Addiction's Issues of Substance 2021 [Virtual].

*Dowson, M. E., Bossom, I. R. L., Salmon, M. M., Tabri, N., \& Wohl, M. J. A. (2021, October). Should I Stay or Should I Go: Feeling Both Optimistic for Recovery and Nostalgic for Gambling Heightens Ambivalence and Likelihood of Relapse. Poster presented at the 22nd annual conference of the International Center for Responsible Gaming [Virtual].

*Most Outstanding Poster Award

Stefaniak, A., \& Wohl, M.J.A. (July, 2021). Different pasts for different political folk: Political orientation predicts collective nostalgia content. 44th ISPP Annual Meeting [Virtual].

France, J., Salmon, M. M., \& Wohl, M. J. A. (2021, June). When the Past is Fraught with Danger: A negative past limits nostalgia's behaviour change utility. Poster to be presented at the $82^{\text {nd }}$ Annual Canadian Psychological Association (CPA) Conference [Virtual]. 
*Stark, S., Price, A., Balodis, I., Tabri, N., \& Wohl, M. J. A. (2021, June). Young adults and gambling during the COVID-19 pandemic: Results from a longitudinal survey of Ontario gamblers. Paper presented at the National Conference on Gambling Addiction \& Responsible Gambling 2021 [Virtual].

* Most Outstanding Poster Award

Bossom, I. R. L., Dowson, M. E., Salmon, M. M., Tabri, N., \& Wohl, M. J. A. (2021, June). Longing for the positive feedback received whilst engaged in disordered eating behaviors: Nostalgia as a facilitator of relapse. Poster to be presented at the International Conference on Eating Disorders [Virtual].

Dowson, M. E., Bossom, I. R. L., Salmon, M. M., Tabri, N., \& Wohl, M. J. A. (2021, April). Longing for the game: Nostalgia predicts relapse among people living with gambling disorder. Poster presented at the 20th Annual conference of the Alberta Gambling Research Institute (AGRI) [Virtual].

Bossom, I. R. L., Dowson, M. E., Salmon, M. M., Tabri, N., Wohl, M. J. A. (2021, February). Nostalgic reverie as a facilitator of relapse in eating disorder psychopathology and behaviors. Poster presented at the Society for Personality and Social Psychology (SPSP) conference [Virtual].

Balodis, I., Price, A., Stark, S., Tabri, N., \& Wohl, M. J. A. (2021, April). Co-use of substances in a longitudinal survey of Ontario gamblers during the COVID-19 pandemic. Poster presented at the $20^{\text {th }}$ Annual Conference of the Alberta Gambling Research Institute [Virtual].

Higgison, K., Wohl, M. J. A., \& Stefaniak, A. (2021, February): Making men great again: Longing for traditional gender roles undermines men's support for gender equality. Poster presented at the Society for Personality and Social Psychology (SPSP) conference [Virtual].

Stefaniak, A., Wohl, M.J.A., \& Mallett, R. K. (2021, February). Their gain is our loss: Zero-sum beliefs shape advantaged groups' support for collective action. Poster presented at the Society for Personality and Social Psychology (SPSP) conference [Virtual].

Leslie, D., Kim, H.S., Rockloff, M., McGrath, D.S., Wohl, M.J.A., \& Hodgins, D.C. (2020, May). Assessing gambling motives and impulsivity in gamblers who do and do not purchase loot boxes. Poster presented at the 16th annual Hotchkiss Brain Institute Research Day, Calgary, AB.

Xie, E. B., Salmon, M. M., Wohl, M. J. A., \& Davis, C. G. (2020, July). Is my secret safe? Fear of discovery and disclosure following infidelity. Poster presented at the International Association for Relationship Research Conference, London, UK.

Xie, E. B., Salmon, M. M., Wohl, M. J. A., \& Davis, C. G. (2020, May). Disclosing infidelity in romantic relationships. Talk presented at the Canadian Psychological Association, Montreal, Canada.

Tippins, E., Salmon, M. M., Tabri, N., \& Wohl, M. J. A. (2020, May). Addictive identity centrality predicts impairment. Poster accepted for presentation at the 81st Annual Convention of the Canadian Psychological Association in Montreal, QC.

Leslie, D., Kim, H.S., Rockloff, M., McGrath D.S., Wohl, M.J.A., \& Hodgins, D.C. (2020, March). Does offering tangible rewards in social casino games influence gameplay intensity or future gambling? Preliminary findings. Poster to be presented at the Alberta Gambling Research Institute Conference, Banff, AB.

Ritchie, E.V., Mutti-Packer, S., McGrath, D.S., Kim, H.S., Rockloff, M., Wohl, M.J.A., \& Hodgins, D.C. (2020, March). Pop-up messages for internet gambling: An experimental study examining the efficacy of fear appeals. Poster to be presented at the Alberta Gambling Research Institute Conference, Banff, AB.

Hollingshead, S. J. \& Wohl, M. J. A. (2019, May). Rewarding responsible gambling may increase tool use and attitudinal loyalty: A survey of members who do and do not currently use responsible gambling tools. Paper presented at the International Conference on Gambling \& Risk Taking, Las Vegas, NV. 
Salmon, M. M., Tabri, N., \& Wohl, M. J. A. (2019, May). “I am a gambler”: Identity centrality predicts disordered gambling symptomatology. Paper presented at the International Conference on Gambling \& Risk Taking, Las Vegas, NV.

Wohl, M. J. A. (2019, May). Loyalty programs in the gambling industry: Understanding the risks and potential for marm minimization. Paper presented at the International Conference on Gambling \& Risk Taking, Las Vegas, NV.

Davis, C. G., \& Wohl, M. J. A. (2019, March). Self-imposed limit-setting and positive play. Poster presented at Alberta Gambling Research Institute Conference, Banff, AB.

*Guidry, A., Kim, H. S., Rockloff, M., Leslie, D., Hodgins, D. C., McGrath, D. S., \& Wohl, M. J. A. (2019, March). Assessing the correlates of problematic social casino gaming. Poster presented at Alberta Gambling Research Institute Conference, Banff, AB.

* Most Outstanding Poster Award

Kim, H. S., Leslie, D., Rockloff, M., Hodgins, D. C., McGrath, D. S., \& Wohl, M. J. A. (2019, March). An experimental study of the social casino gaming-gambling link: Testing the role of inflated payout rates and psychological characteristics on the decision to gamble. Poster presented at Alberta Gambling Research Institute Conference, Banff, Alberta.

Wood, R. T. A., Wohl, M. J. A., Tabri, N., \& Philander, K. (2018, September). Optimising responsible gambling strategy in Canada: National benchmarking using the Positive Play Scale (PPS). Paper presented at $12^{\text {th }}$ European Conference on Gambling Studies and Policy Issues, Valletta, Malta.

Chayinska, M., Kende, A., \& Wohl, M. J. A. (2018, June). Perceived historical oppression leads majority group members to protect the in-group's future vitality by undermining the rights of minority groups. Paper presented at Society for the Psychological Study of Social Issues Conference, Pittsburgh, PA.

Orazani, S. N., Wohl, M. J. A., \& Leidner, B. (2018, June). How normalization of extreme political views leads to political tolerance? Paper presented at Society for the Psychological Study of Social Issues Conference, Pittsburg, PA.

Wohl, M. J. A., Hollingshead, S. J., Tabri, N., Dupuis, D. R., \& Caouette, J. (2018, May). What will become of them? Empathetic collective angst motivates perpetrator group members to protect the future vitality of the victimized group. Paper presented at the 30th Annual Convention of the Association for Psychological Science in San Francisco, CA.

Tabri, N., Hollingshead, S. J., \& Wohl, M. J. A. (2018, March). Group-based existential threat and mental health: Anxiety symptoms elevate among people preoccupied with group-based existential threat via collective angst. Poster presented at the Society for Personality and Social Psychology (SPSP) conference, Atlanta, GI.

Hollingshead, S. J., Wohl, M. J. A., Dupuis, D. R., \& Tabri, N. (2018, March). Empathetic collective angst promotes support for policies that protect the future vitality of a victimized group (even if those policies discriminate against the perpetrator group). Poster presented at the Society for Personality and Social Psychology (SPSP) conference, Atlanta, GI.

Davis, C. G., Hollingshead, S. J., \& Wohl, M. J. A. (2018, January). I lost how much? Effects of player-account feedback on subsequent play. Poster presented at The New Horizons in Responsible Gambling Conference, Vancouver, BC.

*Hollingshead, S. J., Wohl, M. J. A., \& Davis, C. G. (2017, May). Providing players with accurate information about monetary loss over a three-month span reduces subsequent gambling. Poster presented at the Life Science Research Day, Ottawa, ON.

* Most Outstanding Poster Award

Tabri, N., Wohl, M. J. A., Eddy, K. T., \& Thomas, J. J. (2017, May). When financial success defines the self: The 
consequences of overvalued ideation about financial success for disordered gambling. Paper presented at the 29th Annual Convention of the Association for Psychological Science in Boston, MA.

Hollingshead, S. J., Wohl, M. J. A., \& Davis, C. G. (2017, April). Providing players with accurate information about monetary loss over a three month span reduces subsequent gambling. Poster presented at the 2017 Discovery Conference, Toronto, Ontario.

Salmon, M. M., Wohl, M. J. A., Kim, H. S., Santesso, D., Wildschut, T., \& Sedikides, C. (2017, April). Looking back to move forward: Self-discontinuity (via nostalgia) motivates attempts to change among disordered gamblers. Poster presented at the 2017 Discovery Conference, Toronto, Ontario.

*Lidstone, S. K., Tabri, N., Castano, E., \& Wohl, M. J. A. (2017, January). ISIS, collective angst, and isolationism: Feeling existential threat Undermines support for Syrian refugees via concern for America's future. Poster presented at the Society for Personality and Social Psychology (SPSP) conference, San Antonio, TX.

* Best Poster Award - Finalist

Hornsey, M. J., Okimoto, T., Wenzel, M., \& Wohl, M. J. A. (2016, September). Why collective apologies promote forgiveness less than interpersonal apologies: The problem (and solution) lies in communicating sincerity. Paper presented at the Society for Experimental Social Psychology Conference, Santa Monica, CA.

Kachanoff, F.J., Caouette, J., Wohl, M.J.A., \& Taylor, D.M. (2016, June). Allowing the victim to draw a line in history: Intergroup apology effectiveness as a function of collective autonomy support. Paper presented at the Canadian Psychological Association Annual Convention (CPA), Victoria, BC.

Kachanoff, F.J., Taylor, D.M., Caouette, J., Wohl, M.J.A., \& Khullar, T., (2016, June). The Chains on all of my people were the chains on me: Considering intergroup contexts within self-determination theory. Paper presented at the Canadian Psychological Association Annual Convention (CPA), Victoria, BC.

*Hollingshead, S. J., Kim, H. S., Wohl, M. J. A., \& Derevensky, J. (2016, June). Motivation for playing social casino games predicts whether gambling increases or decreases. Poster presented at the 16th International Conference on Gambling and Risk Taking, Las Vegas, Nevada.

* Most Outstanding Award

Salmon, M. M., Kim, H. S., \& Wohl, M. J. A. (2016, June). Optimism undermines the positive influence nostalgic revere for the pre-addicted self has on readiness to change. Poster presented at the $16^{\text {th }}$ International Conference on Gambling and Risk Taking, Las Vegas, Nevada.

Wohl, M. J. A., Kim, H. S., Salmon, M., Santesso, D., Wildschut, T., \& Sedikides, C. (2016, June). Moving forward by looking back: Feeling disconnected from the past (non-addicted self) motivates behavioral change. Paper presented at the $16^{\text {th }}$ International Conference on Gambling and Risk Taking, Las Vegas, Nevada.

*Kim, H. S., \& Wohl, M. J. A. (2016, May). Longing for the Non-Addicted Self: Self-Discontinuity Increases Readiness to Change via Nostalgia. Poster presented at the 2016 Canadian Cognitive Behavioral Therapy Conference, Hamilton, Ontario.

* Most Outstanding Poster Award

Kim, H. S., Wohl, M. J. A., Salmon, M. M., Gupta, R., \& Derevensky, J. (2016, February). Do social casino gamers migrate to online gambling? An assessment of migration rate and potential predictors. Paper presented at the 2016 International Gambling Conference, Auckland, New Zealand

Sztainert, T., Wohl, M. J. A. \& Abizaid, A. (2016, February). Hungry to gamble? How craving, hunger, and hormones affect play. Poster presented at The New Horizons in Responsible Gambling Conference, Vancouver, BC.

Hackel, L. M., Coppin, G., Wohl, M. J. A., Zaki, J., \& Van Bavel, J. J. (2016, January). From grits to giving: Identity shapes valuationacross non-social and social preferences. Poster presented at the 17 th annual meeting of the Society for Personality and Social Psychology, San Diego, CA. 
Hornsey, M. J., Barlow, F. K., Thai, M., \& Wohl, M. (2015, September). Apologizing to the mirror: Perpetrator groups can enhance their moral self-image by accepting their own apologies. Paper presented at the Annual Meeting of the Society of Experimental Social Psychology. Denver, USA.

Salmon, M. M., Kim, H. S., \& Wohl, M. J. A. (2015, September). In the mindset for change: Implicit theories moderate the effect of self-discontinuity and nostalgia on behavioural change among disordered gamblers. Poster presented at the $16^{\text {th }}$ Annual National Center for Responsible Gaming Conference on Gambling and Addiction, Las Vegas, Nevada

Salmon, M. M., Wohl, M. J., Kim, H. S., \& Santesso, D. (2015, June). Overcoming barriers to behavioural change via nostalgic revere for the pre-addicted self. Poster presented at the Summer Interactive Symposium, Montreal, Quebec

*Kim, H. S., Wohl, M. J. A, Derevensky, J., Hollingshead, S., Salmon, M. M., \& Gupta, R. (2015, June). Social casino games: The good and the bad. Poster presented at Concordia's Summer Interactive Symposium - Research 2.0, Montreal, Quebec.

* Most Outstanding Poster Award

Dupuis, D. R. \& Wohl, M. J. A. (2015, June). Why are atheists distrusted? The respective roles of lack a watchful God and perceived lack moral foundations. Poster presented at Canadian Psychological Association, 76th Annual Convention. Ottawa, ON.

Dupuis, D. R. \& Wohl, M. J. A. (2015, June). What to do with Edward Snowden? Reputational harm interacts with political orientation to predict desire to punish a leaker of classified information. Poster presented at Canadian Psychological Association, 76th Annual Convention. Ottawa, ON.

Salmon, M. M., Wohl, M. J. A., Kim, H. S., \& Davis, C. G. (2015, June). A cocktail for change: Nostalgic revere for the pre-addicted self and self-efficacy interact to predict readiness to change among problem drinkers. Poster presented at Canadian Psychological Association, 76th Annual Convention. Ottawa, ON.

Tabri, N., Dupuis, D. R., Kim, H. S., \& Wohl, M. J. A. (2015, June). When 'Movin' On Up' is not possible: Perceived social mobility moderates the effect of relative deprivation on financial motives and disordered gambling symptomatology. Poster presented at Canadian Psychological Association, 76th Annual Convention. Ottawa, ON.

Dupuis, D. R. \& Wohl, M. J. A. (2015, May). Moral decay: Theists perceive atheists' morality to decrease as a function of their generational distance from religious ancestors. Poster presented at the 27th Annual Convention of the Association for Psychological Science, New York, NY..

Tabri, N., Wohl, M. J. A., \& Caouette, J. (2015, May). Antecedents of collective angst: Perceptions of harm probability, harm severity, and collective efficacy. Poster presented at the 27th Annual Convention of the Association for Psychological Science, New York, NY.

Wohl, M. J. A., Cohen-Chen, S., Halperin, E., Caouette, J., Hayes, N., \& Hornsey, M. J. (2015, May). Belief in the malleability of groups strengthens the collective apology-forgiveness link. Paper presented at the 27th Annual Convention of the Association for Psychological Science, New York, NY

Packer, D. J., Miners, C. T. H, Wohl, M. J. A. \& Dupuis, D. R. (2015, May). Tough love for the long haul: How dissent decisions are influenced by temporal perspective. Paper presented at the Society for the Study of Motivation Conference, New York, NY.

Kim, H. S., Hollingshead, S., Wohl, M. J. A. \& Derevensky, J. (2015, April). Do social casino gamers migrate to online gambling? An assessment of migration rate and potential predictors. Poster presented at 2015 Discovery Conference, Toronto, ON.

Hornsey, M. J., Barlow, F. K., Okimoto, T., Thai, M., Wenzel, M., \& Wohl, M. J., A. (2015, April). Intergroup apologies from the perpetrator's perspective. Paper presented at the SPSSI-SASP Small Groups 
Conference on Collective Harm-doing: Developing the Perspective of the Perpetrator, Brisbane, QSLD, Australia.

Salmon, M. M., Wohl, M. J. A., Kim, H. S., \& Santesso, D. (2015, March). Nostalgic revere for the pre-addicted self motivates behavioural change among disordered gamblers. Poster presented at the 14th Alberta Gambling Research Institute Conference, Banff, AB.

Sztainert, T., Kim, H. S., Wohl, M. J. A., \& Salmon, M. (2015, March). Knowledge translation and exchange in gambling: A researchers guide. Poster presented at the 14th Alberta Gambling Research Institute Conference, Banff, AB.

*Kim, H. S., Wohl, M. J. A., Salmon, M. M., Gupta, R., Derevensky, J. (2015, February). Do social casino gamers migrate to online gambling? An assessment of migration rate and potential predictors. Poster presented at the New Horizons in Responsible Gambling Conference, Vancouver, BC.

* Most Outstanding Poster Award

Dupuis, D. R., McLaughlin, K., Sztainert, T., \& Wohl M. J. A. (2014, July). Godlessness as an existential threat: AntiAtheist prejudice is driven by collective angst-inducing similarity to Christianity. Paper presented at European Association of Social Psychology Conference, Amsterdam, Netherlands.

Gur, T., Porat, R., Tamir, M, Wohl, M. J. A., \& Halperin, E. (2014, July). Emotional preferences for collective angst. Paper presented at the Annual Scientific Meeting of the International Society of Political Psychology, Rome, Italy.

Hornsey, M. J., Barlow, F. K., Thai, M., \& Wohl, M. J. A. (2014, July). Apologizing to the mirror: How perpetrator groups gain moral redemption even after substandard apologies. Paper presented at the Annual Scientific Meeting of the International Society of Political Psychology, Rome, Italy.

Hornsey, M. J., Barlow, F. K., Thai, M., \& Wohl, M. J. A. (2014, June). Apologizing to the mirror: How transgressor groups balance their desire for moral redemption and their motivation to minimize perpetrator status. Paper presented at the European Association of Social Psychology small group meeting on collective victimization, Verona, Italy.

Hornsey, M. J., Barlow, F. K., Thai, M., \& Wohl, M. J. A. (2014, June). Apologizing to the mirror: Extending the needs based model of reconciliation for perpetrator group members. Paper presented at the $15^{\text {th }}$ biannual International Society for Social Justice Conference, New York, NY.

Wohl, M. J. A., Xiao, Y. J., \& Van Bavel, J. J. (2014, June). Collective apologies attenuate perceptual biases that stem from intergroup threat: A test of the perception under threat (PUT) model of intergroup relations. Paper presented at the $15^{\text {th }}$ biannual International Society for Social Justice Conference, New York, NY.

Hornsey, M.J., Barlow, F.K., Okimoto, T., Thai. M., Wenzel, M., \& Wohl, M. (2014, April). Intergroup apologies from the perpetrator's perspective. SPSSI-SASP small group meeting, Brisbane.

Kim, H. S., Salmon, M. M., \& Wohl, M. J. A. (2014, April). Longing for the non-gambling self: A sense of selfdiscontinuity facilitates readiness to change via nostalgia among disordered gamblers. Poster presented at the 13th Alberta Gambling Research Institute Conference, Banff, Alberta.

Kim, H. S., Wohl, M. J. A., Stewart, M., Sztainert, T., \& Gainsbury, S. (2014, April). Pre-committing to a time limit promotes responsible gambling in a sample of student EGM gamblers. Poster presented at the 2014 Discovery Conference, Toronto, Ontario.

*Sztainert, T., Wohl, M. J. A. \& Abizaid, A (2014, April). Starving to gamble: Hunger and gambling-related craving interact to heighten persistent play among problem gamblers. Poster presented at Alberta Gambling Research Institute's 13th Annual Conference, Banff, Alberta.

* Best Poster Award 
Wohl, M. J. A., Halprin, E., Hornsey, M. J., \& Cohen-Chen, S., (2013, July). Understanding the pitfalls of saying sorry via the staircase model of intergroup apology effectiveness. Paper presented at the Annual Scientific Meeting of the International Society of Political Psychology. Herzliya, Israel.

Gupta, R., Derevensky, J. L., \& Wohl, M. J. A. (2013, May). A qualitative examination of online gambling culture among college students: Preliminary evidence and future directions toward identifying factors influencing participation, maintenance and cessation. Paper presented at the 15th International Conference on Gambling and Risk-taking, Las Vegas, NV.

Mitchell, K., Kim, H., Wohl, M.J. A., \& Parush, A. (2013, May). Facilitating responsible gambling through persuasive technology: Using human-computer interaction principles to better monetary limits. Paper presented at the 15th InternationalConference on Gambling and Risk-taking, Las Vegas, NV.

Sztainert, T., Wohl, M. J. A. \& Abizaid, A (2013, May). Starving to gamble: Hunger and gambling-related craving interact to heighten persistent play among problem gamblers. Paper presented at the $15^{\text {th }}$ International Conference on Gambling and Risk-taking, Las Vegas, NV.

Lister, J. J., Nower, L., \& Wohl, M. J. A. (2013, May). Goal setting, chasing, and persistence during slot machine play. Paper presented at the $15^{\text {th }}$ International Conference on Gambling and Risk Taking, Las Vegas, NV.

Lister, J. J., Nower, L., \& Wohl, M. J. A. (2013, May). The relationship of vulnerability factors and persistence during slot machine play. Paper scheduled for presentation at the $15^{\text {th }}$ International Conference on Gambling and Risk Taking, Las Vegas, NV.

Lister, J. J., Wohl, M. J. A., \& Davis, C. G. (2013, April). The dark side of authenticity: Feeling "real" while Gambling interacts with enhancement motives to predict problematic gambling behaviour. Poster presentedat the $12^{\text {th }}$ annual meeting of the Alberta Gambling Research Institute, Banff, AB.

Wohl, M. J. A., Hornsey M., Matheson, K., Branscombe, N. R., \& Anisman, H. (2013, January). Collective guilt assignment moderates expected outcomes of an intergroup apology and willingness to forgive: A test of the staircase model of intergroup apology effectiveness. Paper presented in the symposium "Life is an Adventure in Forgiveness": Surprising Lessons in Giving and Gaining Forgiveness" Chaired by G. Freedman and J. S. Beer at the 14th annual meeting of the Society for Personality and Social Psychology (SPSP), New Orleans, LA.

Giguère, B., Wohl, M. J. A., \& Taylor, D. M. (2013, January). The impact of collective angst on the cohesion of a group. Poster presented at the 14th annual meeting of the Society for Personality and Social Psychology (SPSP), New Orleans, LA.

Antaya, G., Wohl, M. J. A., Taylor, D. M., \& King, M. (2013, January). Religioius zeal predicts support of militant action via social dominance orientation. Poster presented at the 14th annual meeting of the Society for Personality and Social Psychology (SPSP), New Orleans, LA.

Wohl, M. J. A., King, M., \& Taylor, D. M., (2012, July). Expressions of political practice: Collective angst moderates politicized collective identity to predict peaceful and violent protest. Paper presented at the Annual Scientific Meeting of the International Society of Political Psychology. Chicago, IL.

Gillen, N. R., Wohl, M. J. A., \& Harasymchuk, C. (2012, June). Transgression severity moderates the positive relationship between relational boredom and self-forgiveness. Paper presented in the Advances in Measurement and Conceptualization in the Study of Forgiveness and Unforgiveness Symposium at the 73nd Annual Convention of the Canadian Psychological Association, Halifax, NS.

Sztainert T., Wohl, M. J. A., Stead, J., Anisman, H., \& Matheson, K. (2012, April). Gambling motivations predict reward drive among problem gamblers. Poster presented at the Alberta Gambling Research Institute's $11^{\text {th }}$ Annual Conference, Banff, Alberta. 
Wohl, M. J. A., Branscombe, N., \& Lister, J. J. (2012, April). When the going gets tough, the tough get betting: Poor economic prospects increase gambling behavior. Paper presented at the Alberta Gambling Research Institute's 11th Annual Conference, Banff, AB.

Gillen, N., Wohl, M. J. A., \& Harasymchuk, C. (2012, January). Relational boredom and willingness to engage in infidelity: The role of self-forgiveness. Poster presented at the 13th annual meeting of the Society for Personality and Social Psychology (SPSP), San Diego, CA.

Squires, E., Wohl, M. J. A., \& Davis, C. G. (2012, January). Why the Powerful Forgive: The Function of Partner Blame and Relationship Satisfaction Following Infidelity. Poster presented at the 13th annual meeting of the Society for Personality and Social Psychology (SPSP), San Diego, CA

Wohl, M. J. A., \& Stewart, M. J. (2011, December). Playing within your limits: Factors impacting adherence to monetary limits in a session of slot machine gambling. Poster presented at the 2011 Heath Research Showcase, Toronto, ON.

Young, M. M., Wohl, M. J. A. \& Sztainert, T. (2011, November). The Gambling Craving Scale: Psychometric validation and behavioral outcomes. Poster presented at Issues of Substance (the Canadian Centre on Substance Abuse national conference), Vancouver, British Columbia.

Sztainert, T. K., Squires, E. C., Gillen, N., Caouette, J., \& Wohl, M. J. A. (2011, October). The problem with self forgiveness: Forgiving the self deters readiness to change in gamblers. Poster presented at the 12th Annual NCRG Conference on Gambling and Addiction, Las Vegas, Nevada.

Wohl, M. J. A. (2011, July). When ingroup representation focuses on existential vulnerability:

The effect of collective angst on intergroup relations. Paper presented at the Meeting of the European Association of Experimental Social Psychology (EAESP), Stockholm, Sweden.

Wohl, M. J. A., \& Stewart, M. J. (2011, April). Playing within your limits: Factors impacting adherence to monetary limits in a session of slot machine gambling. Poster presented at the 2011 Alberta Gambling Research Institute Conference, Banff, AB.

Sztainert, T. K., Squires, E. C., Gillen, N., Caouette, J., \& Wohl, M. J. A. (2011, March). Forgiving the self for gambling undermines readiness to change. Poster presented at the $3^{\text {rd }}$ annual Young Researchers' Conference, Ottawa, Ontario.

Squires, E., Wohl, M. J. A., \& Davis, C. G. (2011, January). The Impact of Meaning Making on Forgiveness Following Infidelity. Poster presented at the $12^{\text {th }}$ annual meeting of the Society for Personality and Social Psychology (SPSP), San Antonio, TX.

Wohl, M. J. A. (2010, August). The antecedents an consequences of collective angst for intra-group relations. Paper presented at the meeting of the International Society for Justice Research, Banff, AB, Canada.

Wohl, M. J. A., \& Hornsey, M. (2010, June). Why group apologies succeed and fail: Intergroup forgiveness and the role of primary and secondary emotions. Paper presented at the $71^{\text {st }}$ Annual Convention of the Canadian Psychological Association (CPA), Winnipeg, MB.

Squires, E., \& Wohl, M. J. A. (2010, January). Timing is everything: When an apology is given affects empathy, perceived responsibility, relationship closeness, and willingness to forgive. ? Poster presented at the $11^{\text {th }}$ annual meeting of the Society for Personality and Social Psychology (SPSP), Las Vegas, NV.

Kiu, L., Wohl, M. J. A., Raspopow, K., Matheson, K. \& Anisman, H. (2009, August). Discrimination, ingroup forgiveness, and support of the outgroup victim. Poster presented at the $117^{\text {th }}$ Annual Convention of the American Psychological Association (APA) Convention, Toronto, ON, Canada.

Philpot, C. R., Hornsey, M. J., \& Wohl, M. J. A. (2009, July). Apologies between groups: The view from both sides. Paper presented at the 17th Brisbane Symposium on Social Identity, Brisbane, Australia. 
Sztainert, T., \& Wohl, M. J. A (2009, May). Missing those who need help the most: How attrition in longitudinal research differs among gambling pathology and willingness to change. Paper presented at the $14^{\text {th }}$ International Conference on Gambling and Risk-Taking, Lake Tahoe, CA.

Stewart, M. J., Wohl, M. J. A., \& Young, M. M. (2009, May). Luck as a personal possession: Analysis of a measure of personal luck related to gambling. Paper presented at the $14^{\text {th }}$ International Conference on Gambling and Risk-Taking, Lake Tahoe, CA.

Young, M. M. \& Wohl, M. J. A.(2009, May). The gambling craving scale: Psychometric validation and behavioral outcomes. Paper presented at the $14^{\text {th }}$ International Conference on Gambling and Risk-Taking, Lake Tahoe, CA.

Christie, K., Wohl, M. J. A., Anisman, H., \& Matheson, K. (2009, February). Are educational animations effective in correcting cognitive distortions and reducing problematic play among slots players? Poster presented at the $10^{\text {th }}$ annual meeting of the Society for Personality and Social Psychology (SPSP), Tampa, FL.

Squires, E.C., Wohl, M. J. A., Jetten, J. (2009, February). The past, the future, and intragroup action: The relations among collective continuity threats, collective angst, and the desire to hold on to the past. Poster presented at the $10^{\text {th }}$ annual Meeting of the Society for Personality and Social Psychology (SPSP), Tampa, FL.

Taha, S., Wohl, M. J. A., Matheson, K., \& Anisman, H. (2009, February). Threat appraisals and coping strategies in relation to problematic gambling. Poster presented at the $10^{\text {th }}$ annual meeting of the Society for Personality and Social Psychology, Tampa, FL.

Wohl, M. J. A. \& Bennett, S. H. (2008, August). Attributing versus expressing primary and secondary emotions: The complicated relationship between infrahumanization and intergroup forgiveness. Paper presented at the meeting of the International Society for Justice Research, Adelaide, Australia.

Jetten, J., Iyer, A., Wohl, M. J. A., \& Hutchison, P. (2008, June). Holding on to the Past: Collective continuity and resistance to change. Paper presented at the Meeting of the European Association of Experimental Social Psychology (EAESP), Opatija, Croatia.

Wohl, M. J. A. \& Branscombe, N. R. (2008, June). Remembering historical victimization: Collective guilt for current ingroup transgressions. Paper presented at the Meeting of the European Association of Experimental Social Psychology (EAESP), Opatija, Croatia.

Bennett, S., Wohl, M. J. A. \& Pychyl, T. A. (2008, February). Self-forgiveness for task-specific procrastination. Poster presented at the Meeting of the Society for Personality and Social Psychology (SPSP), Albuquerque, NM.

Christie, K. L., Anisman, H., Wohl, M. J. A., \& Matheson, K. (2008, February). Illusions of control and pathological gambling: Moderating effects of coping and gender. Poster presented at the Meeting of the Society for Personality and Social Psychology (SPSP), Albuquerque, NM.

Donnelly, C. L., Matheson, K., Wohl, M. J. A., \& Anisman, H. (2008, February). Why do Young Women and Men Gamble Problematically? Understanding the Connections between Friendships, Avoidance Coping, and Gambling. Poster presented at the Meeting of the Society for Personality and Social Psychology (SPSP), Albuquerque, NM.

Young, M. M., Wohl, M. J. A., Matheson, K., and Anisman, H. (2007, November). The desire to gamble: The influence of outcomes on the priming effects of a gambling episode/. Poster presented at the 8th Annual NCRG Conference on Gambling and Addiction, Las Vegas, Nevada.

Bennett, S. B. \& Wohl, M. J. A. (2007, June). Forgiving yourself for procrastinating. Poster presented at the $68^{\text {th }}$ annual convention of the Canadian Psychological Association, Ottawa, ON 
Lyon, M., Wohl, M. J. A., Young, M. M., Donnelly, C., Matheson, M., \& Anisman, H. (2007, June). Why gamblers stop engaging in play within a given session. Poster presented at the $68^{\text {th }}$ annual convention of the Canadian Psychological Association, Ottawa, ON

McGrath, A. L., \& Wohl, M. J. A. (2007, June). Would you forgive a traitor? Poster presented at the $68^{\text {th }}$ annual Convention of the Canadian Psychological Association, Ottawa, ON.

McVicar, D., N., \& Wohl, M. J. A. (January, 2007). Salience of victimization history promotes anxiety and ingroup protective behaviour in Jewish people. Paper presented at the $68^{\text {th }}$ annual convention of the Canadian sychological Association, Ottawa, ON.

Ysseldyk, R. L., Wohl, M. J. A., \& Otten, A. (2007, June). I forgive therefore I am committed: The effect of forgiving your romantic partner on relational commitment. Poster presented at the $68^{\text {th }}$ annual convention of the Canadian Psychological Association, Ottawa, ON

Young, M. M., Wohl, M. J. A., Matheson, K., \& Anisman, H (2007, March). An Investigation of craving using a virtual reality casino. Paper presented at the $6^{\text {th }}$ annual Alberta Gaming Research Institute Conference, Banff, AB.

McVicar, D., N., \& Wohl, M. J. A. (January, 2007). Collective angst: Concern for the future vitality of the ingroup and its effect on ingroup protective behaviors. Poster presented at the Meeting of the Society for Personality and Social Psychology (SPSP), Memphis, TN.

Donnelly, C. L., Matheson, K., Wohl, M. J. A., \& Anisman, H. (2007, January). Friendship support and gambling behaviors among young men and women: The Mediating Role of Depression. Poster presented at the Meeting of the Society for Personality and Social Psychology (SPSP), Memphis, TN.

McGrath, A., \& Wohl, M. J. A. (2007, January). You traitor: Anger and forgiveness when an ingroup member forges an alliance with the outgroup. Poster to be presented at the Meeting of the Society for Personality and Social Psychology (SPSP), Memphis, TN.

Young, M. M., Baumann, S. Wohl, M. J. A., Matheson, K., Rachel Thompson, Gregg Stangl, and Scott Fetzick \& Anisman, H (2006, June). A study of gambling using a virtual casino. Paper presented at the $11^{\text {th }}$ Annual CyberTherapy Conference, Gatineau, QC.

Thompson, A., Wohl, M. J. A., \& Boule-Perroni, C. (2006, June). Self-forgiveness and smoking cessation: Emotional arousal and motivation for quitting. Poster presented at the Social and Personality Section Pre conference for the 67th Annual Convention of the Canadian Psychological Association (CPA), Calgary, AB.

Wohl, M. J. A. (2006, June). Our section: The past, present and future of CPA:S-P. Paper presented at the Social and Personality Section Pre-conference for the 67th Annual Convention of the Canadian Psychological Association (CPA), Calgary, AB.

Wohl, M. J. A., Young, M. M., Matheson, K., \& Anisman, H. (2006, May). Outcome expectancies, subjective appraisals, and treatment readiness: The role of perceived personal luck in pathological gambling behavior. Paper presented at the $13^{\text {th }}$ International Conference on Gambling and Risk Taking, Lake Tahoe, CA.

Wohl, M. J. A. (2006, January). The perception of time heals all wounds: Subjective temporal distance and the forgiveness of others. Poster presented at the Meeting of the Society for Personality and Social Psychology (SPSP), Palm Springs, CA.

Wohl, M. J. A. (2005, June) Forgiveness in an intergroup context: The role of group identification following intergroup aggression. Paper presented in B. Giguère (Chair) symposium, Canadian perspectives on social identity: Novel paths to understanding intergroup relations, at the 66th Annual Convention of the Canadian Psychological Association (CPA), Montreal, QC. 
Young, M. M., Wohl, M. J. A., \& Hart, K. E. (2005, June). Self-perceptions of personal luck and probability of treatment entry: Gamblers reporting problems with games that blend elements of skill and chance. Poster presented at the 66th Annual Convention of the Canadian Psychological Association (CPA), Montreal, QC.

Davis, C. G., Wohl, M. J. A., \& Verberg, N. (2005, May). Meaning and posttraumatic growth in the wake of senseless tragedy. Poster presented at Conference on Health Psychology Perspectives on Postive Life Changes, Benefit-finding, and Growth following Illness, Storrs, CT.

Wohl, M. J. A. (2005, January). Understanding forgiveness in an intergroup context. Paper presented in M. J. A. Wohl and R. P. Brown (Chairs) symposium, Frontiers in Forgiveness Research, at the 6th annual meeting of the Society for Personality and Social Psychology (SPSP), New Orleans, LA.

Wohl, M. J. A., \& Brown, R. P. (2005, January). Frontiers in forgiveness research. Co-chair and co-organizer of symposium presented at the 6th annual meeting of the Society for Personality and Social Psychology (SPSP), New Orleans, LA.

Lister, M. B., Wohl, M. J. A., Rocznik, A., \& Kuiken, D. (2005, January). The ways we seek forgiveness: A phenomenological study of interpersonal transgressions. Poster presented at the Meeting of the Society for Personality and Social Psychology (SPSP), New Orleans, LA.

Wohl, M. J. A., Young, M. M., \& Hart, K. E. (2004, July). Perceived personal luck facilitates problem gambling and inhibits treatment readiness. Poster presented at the 112th annual meeting of the American Psychological Association (APA), Honolulu, HI.

Van Bavel, J. J., Dion, K. L., Dion, K. K., \& Wohl, M. J. A. (2004, June). The role of implicit prejudice on group serving bias: Testing the ultimate attribution error paradigm. Paper presented in J. Van Bavel (Chair) symposium, A student symposium on intergroup research: Why can't we all just get along? at the 65th Annual Convention of the Canadian Psychological Association (CPA), St. John's, NL.

Griswell, M. L., Reeder, G. D., Pryor, J. B., \& Wohl, M. J. A. (2004, April). Egocentric motive attributions and support or opposition to the war in Iraq. Poster to be presented at the $76^{\text {th }}$ annual meeting of the Midwestern Psychological Association (MPA), Chicago, IL.

Wohl, M. J. A., \& Reeder, G. D., Pryor, J. B., \& Griswell, M. L. (2004, February). Egocentric motive attributions and support or opposition to the war in Iraq. Poster presented at the 5th annual meeting of the Society for Personality and Social Psychology (SPSP), Austin, TX.

Wohl, M. J. A., \& Enzle, M. E. (2003, June). The illusion of control by proxy. Paper presented in M. Wohl (Chair) symposium, New discoveries in social psychology: The "ways" and "whys" of social behavior at the $64^{\text {th }}$ Annual Convention of the Canadian Psychological Association, Hamilton, ON, June 12-14, 2003.

Wohl, M. J. A. (2003, June). Facing discrimination: Response strategies of disadvantaged groups. Chair/organizer of symposium presented at the 64th Annual Convention of the Canadian Psychological Association, Hamilton, ON, June 12-14, 2003.

Wohl, M. J. A., \& Branscombe, N. R. (2003, February). Promoting forgiveness and reducing collective guilt assignment: Reactions by historically victimized groups to their perpetrator group. Paper presented in Toni Schmader (Chair) symposium, From Fear to Forgiveness: Understanding the Emotional and Behavioral Complexity in Intergroup Conflict at the 4th annual meeting of the Society for Personality and Social Psychology (SPSP), Los Angeles, CA.

Wohl, M. J. A., Branscombe, N. R., \& Enzle, M. E. (2002, May). Willingness to forgive and ascribed guilt for today and for yesteryear: Remembering the Holocaust and reactions to the current Palestinian-Israeli conflict. Paper presented in M. Y. Young (Chair) symposium, Ethnopolitical Conflict: Reflections, Impact, and Prevention symposium at the 63rd annual meeting of the Canadian Psychological Association (CPA), Vancouver, BC.

Wohl, M. J. A., \& Enzle, M. E. (2001, May). Near wins and near losses: The behavioral effects of counterfactual 
thinking and personal luck. Paper presented at the 73rd annual meeting of the Midwestern Psychological Association (MPA), Chicago, IL.

Pritchard, E. T., \& Wohl, M. J. A. (2000, July). The relationship between responsibility and forgiveness: Applying the triangle model of responsibility. Poster session presented at the 61st annual meeting of the Canadian Psychological Association (CPA), Ottawa, ON.

Wohl, M. J. A., \& Enzle, M. E. (2000, May). Getting your mojo working through magical thinking: Luck as a personal possession. Paper presented at the 72nd annual meeting of the Midwestern Psychological Association (MPA), Chicago, IL.

Wohl, M. J. A., \& Enzle, M. E. (2000, March). Magical thinking implications for self-perception: Luck as a personal attribute and possession. Paper presented at the $14^{\text {th }}$ annual Joseph R. Royce Research Conference, Edmonton, $\mathrm{AB}$.

Wohl, M. J. A., \& Enzle, M. E. (1999, June). Luck as a personal attribute and possession: The mediating factor of choice. Paper presented at the $1^{\text {st }}$ annual Western Social Psychology Conference (WSPC), Calgary, AB.

\section{b) to academic bodies (invited)}

Wohl, M. J. A. (2022, November). The changing face of responsible gambling: Positive play and how to harness it. Paper presented at McGill University's Raschkowan Lecture series. Montreal, QC.

Wohl, M. J. A. (2022, November). Aims, potential pitfalls, and harm-minimization utility of rewards programs in the gambling industry. Paper presented at National Association for Gambling Studies, Sydney, Australia.

Wohl, M. J. A. (2022, October). The power of language in addiction treatment and responsible gambling. Paper presented at International Center for Responsible Gaming conference, Las Vegas, NV

Wohl, M. J. A. (2022, October). Responsible gambling: Why the low uptake and what can be done about it?. Paper presented at International Center for Responsible Gaming conference, Las Vegas, NV.

Wohl, M. J. A. (2022, February). Words are like dust in the wind: The gap between intergroup apologies and forgiveness and how to close it. Paper presented at Political Apologies Across Cultures conference, Tilburg, NL.

Packer, D. J., Stefaniak, A., Ungson, N. D., \& Wohl, M. J. A. (2021, October). Citizens' concerns about political polarization and their preferences for strong leaders. Paper presented at the Society for Experimental Social Psychology Conference, Santa Barbara, CA.

Tabri, N., \& Wohl, M. J. A. (2021, April). Advancing the Pathways Model: Financially focused self-concept and erroneous beliefs as core psychopathologies in disordered gambling. Paper presented at the 20th Annual Conference of the Alberta Gambling Research Institute. Online

Wohl, M. J. A. (2021, April). Loyalty programs: Potentials for harm and possibilities for harm-minimization. Paper presented at the Alberta Gambling Research Institute annual conference. Online

Wood, R. T.A., Wohl, M. J. A., \& Tabri, N. (2021, March). Around the world with positive play: Trends and findings. Paper presented at the New Horizons Annual Conference, virtual conference.

Wohl, M. J. A. (2021, March). Protecting our future by preserving our past: Collective nostalgia content determines ingroup protective sentiments and behaviour. Paper presented at University of Queensland, Australia. Online

Wohl, M. J. A. (2021, March). The past can help change the future: The behavior change utility of nostalgic reverie. Paper presented at the Mental Health Speaker Series, Carleton University, Ottawa, Canada. Online.

Wohl, M. J. A. (2021, March). Collective nostalgia and its content matter for understanding intra- and intergroup 
attitudes and behaviour. Paper presented at Australia National University, Australia. Online

Wohl, M. J. A. (2020, November). Days of future past: Concern for the future of one's group prompts longing the days of yore (and a desire to reclaim them). Paper presented at Hebrew University, Israel. Online

Wohl, M. J. A. (2020, November). Days of future past: Concern for the future of one's group prompts longing the days of yore (and a desire to reclaim them). Paper presented at Carleton University, Canada. Online

Wood, R. T.A., Wohl, M. J., Tabri, N. (2020, October). Focusing on positive play to optimize responsible gambling strategy. Paper presented at the NASPL Annual Conference. Online.

Wohl, M. J. A. (2020, July). Replicability, open science, and independence in gambling research. Moderator and panellist at the Technology Risk and Gambling Webinar, University of Sydney, Sydney, Australia. Online

Wohl, M. J. A. (2020, May). Group-based existential anxiety and the desire to protect "our" future: The antecedent and consequences of collective angst. Paper presented at the University of Warsaw, Warsaw, Poland. Online

Wohl, M. J. A. (2019, July). Collective nostalgia and the desire to make one's group great again. Paper presented at the Sydney Symposium: Applications of Social Psychology, Visegrad, Hungary

Wohl, M. J. A. (2019, March). What is the utility of responsible gambling programs? Paper presented at the Alberta Gambling Research Institute conference, Banff, AB.

Wohl, M. J. A. (2018, November). Loyalty programs in the gambling industry: The good, the bad, and the ugly. Keynote address at the National Association for Gambling Studies, Brisbane, Australia.

Wohl, M. J. A. (2018, September). Advancing victim need satisfaction: Empathetic collective angst predicts perpetrator group support for the empowerment of their victims. Paper presented at the University of Waterloo, Waterloo, AB.

Wohl, M. J. A. (2017, October). Words are like dust in the wind: Intergroup Apologies and The Rocky Road to Reconciliation. Paper presented at the University of Alberta, Edmonton, AB.

Wohl, M. J. A., Salmon, M., Hollingshead, S. J., \& Tabri, N. (2017, October). The past can help change the future: The behavior change utility of nostalgic reverie for the pre-addicted self. Paper presented at Peter Boris Centre for Addictions Research Rounds, McMaster University, Hamilton, ON.

Wohl, M. J. A., Salmon, M., Hollingshead, S. J., \& Tabri, N. (2017, October). The past can help change the future: The behavior change utility of nostalgic reverie for the pre-addicted self. Paper presented at University of Toronto, Toronto, ON.

Wohl, M. J. A. Davis, C. G., \& Hollingshead, S. J. (2017, April). Loyalty programs: The good, the bad, and the ugly. Paper presented at the Alberta Gambling Research Institute conference, Banff, AB.

Wohl, M. J. A. (2017, March). Loyalty programs and spending. Paper presented at the Carleton University, Department of Psychology Pro-Seminar, Ottawa, ON.

Hornsey, M.J., Okimoto, T., Wenzel, M., \& Wohl, M. (2017, January). Why collective apologies promote forgiveness less than interpersonal apologies (and what to do about it). Group Processes \& Intergroup Relations preconference at Annual Meeting of the Society for Personality and Social Psychology. San Antonio, USA.

Wohl, M. J. A. (2016, December). The rocky road to reconciliation: The curious case of the intergroup apology and its (messy) link to forgiveness. Paper presented at Canadian Counselling Association's Speakers Series Professional Development Event, Ottawa, ON.

Wohl, M. J. A. (2016, October). Words Are like dust in the wind: The tenuous link between intergroup apologies and reconciliation. Paper presented at Queens University, Kingston, ON. 
Wohl M. J. A., Salmon, M., Kim H. S., \& Santesso, D. (2016, September). Overcoming barriers to behavioral change: Implications of new research for clinical practice and research. Paper presented at the National Center for Responsible Gambling conference, Las Vegas Ottawa, ON.

Wohl, M. J. A. (2016, July). The (messy) relationship between collective apologies and reconciliation. Paper presented at the Meeting on Intergroup Psychological Interventions, Stanford University, Palo Alto, CA.

Wohl, M. J. A., Hollingshead, S., Lidstone, S., \& Dupuis, D. (July, 2016). In the aftermath: Empathetic collective angst motivates post-apology engagement. Paper presented at the 16th biannual International Society for Social Justice Conference, Canterbury, UK.

Wood, R.T.A. \& Wohl, M.J.A. (2016, February). Measuring the effectiveness of responsible gambling strategy: Introducing the Positive Play Index. Paper presented at the New Horizons in Responsible Gambling Conference, Vancouver, BC.

Wohl M. J. A., Kim H. S., Salmon, M., \& Santesso, D. (2015, June). Longing for better times: Nostalgia motivates positive change in addictive behavior. Paper presented at the Social and Personality Section Pre-conference of the $76^{\text {th }}$ Annual Convention of the Canadian Psychological Association (CPA), Ottawa, ON.

Wohl, M. J. A., Abizaid, A. \& Sztainert, T. (2015, February). Starving to Gamble. Paper presented at the 2015 Heath Research Showcase, Toronto, ON.

Wohl, M. J.A, Kim, H. S., \& Salmon, M. M. (2015, February). Advances in motivating change among disordered gamblers: Why and how memories of the past-self can facilitate motivation to engage in behavioural change. Paper presented at the New Horizons in Responsible Gambling conference, Vancouver, BC.

Wohl, M. J. A. \& Kim, H. S. (2014, June). The bright side of feeling disconnected with the past self: Self-discontinuity (via nostalgia) increases readiness to change among disordered gamblers. Paper presented at the Ontario Problem Gambling Provincial Forum, Ottawa, ON.

Wohl, M. J. A. (2014, April). Social network gaming: A new frontier for recruiting to-be-gamblers or is the cigar just a cigar? Paper presented at the Canadian Partnership for Responsible Gambling Symposium, Toronto, ON.

Wohl, M. J. A., Gupta, R., Derevensky, J. L, \& Salmon, M. (2014, January). When is play-for-fun just fun? Identifying factors that predict migration from social networking gaming to Internet gambling. Paper presented at the New Horizons in Responsible Gambling conference, Vancouver, BC.

Wohl, M. J. A. (2013, April). Collective angst unplugged: Stripping down the consequences of feeling your group might one day be no more. Paper presented at the University of Syracuse, Syracuse, NY.

Wohl, M. J. A. (2013, April). The multi-generational legacies of victimization: Reminders of the Holocaust promote concerns for Jewish vitality, moral obligation, and ingroup protective behaviours. Paper presented at the If Not Now, When? Responsibility and Memory after the Holocaust conference, Ottawa, ON.

Wohl, M. J. A. (2013, April). Innovations in responsible gambling research: Examining ways to reduce excessive play. Paper presented at the Alberta Gambling Research Institute conference, Banff, AB.

Wohl, M. J. A., Sztainert, T., \& Young, M. M. (2013, January). Antecedents of Gambling-related craving: Implications for initiatives to promote responsible gambling. Paper presented at the New Horizons in Responsible Gambling conference. Vancouver, BC.

Wohl, M. J. A. (2012, August). The staircase model for effective intergroup apologies: Necessary steps (and pitfalls) on route to reconciliation. Invited talk at the EASP Small Group Meeting on Reconciliation in intergroup contexts: The divergent perspectives of perpetrator and victim groups, Sarajevo School of Science and Technology, Sarajevo, Bosnia and Herzegovina. 
Wohl, M. J. A. (2012, April). Helping reviewers understand your paper: How to maximize your acceptance rate. Invited talk at the Alberta Gambling Research Institute conference, Banff, AB.

Wohl, M. J. A. (2012, February). Is it possible for states to forgive? A reply to Wolterstrorff. Invited talk at Possibilities of Forgiveness Conference, Philadelphia, PA.

Wohl, M. J. A. (2012, February). Understanding intergroup forgiveness. Invited talk at Possibilities of Forgiveness Conference, Philadelphia, PA.

Wohl, M. J. A., \& Stewart, M. J. (2011, December). Changing practice: Moving gambling research to implementation. Invited talk at the 2011 Heath Research Showcase, Toronto, ON.

Wohl, M. J. A. (2011, November). In pursuit of protecting your group's future: The constructive and destructive consequences of collective angst. Invited talk at York University, Toronto, ON.

Wohl, M. J. A. Pellizzari, P., \& Stewart, M. J. (2011, October). New research and implications for operators: Player tools, do they work. Invited talk at the Nova Scotia Gambling Conference. Halifax, NS.

Wohl, M. J. A., \& Nower, L. (2011, April). Are loss limits and pre-commitment strategies effective prevention measures for at-risk gamblers? Invited talk at the Alberta Gambling Research Institute conference, Banff, $\mathrm{AB}$.

Wohl, M. J. A. (2011, April). Self-forgiveness: The good, the bad, and the ugly. Invited talk at the University of Calgary, Calgary, AB.

Wohl, M. J. A. (2011, January). The psychology of collective angst. Paper presented at the Group Processes and Intergroup Relations Pre-Conference. San Antonio, TX.

Wohl, M. J. A. (2010, November). Collective angst: How concern for the future of one's group influences intergroup relations. Invited talk at Trent University, Peterborough, ON.

Wohl, M. J. A., Christie, K., \& Stewart, M. J. (2010, October). Responsible gambling, what works? From educational animations to pop-up messages. Invited talk at the Nova Scotia Gambling Conference. Halifax, NS.

Wohl, M. J. A. (2010, June). Collective angst: and the desire to protect the ingroup from possible extinction. Invited talk at New York University, New York, USA.

Wohl, M. J. A. (2010, April). We were, we are, will we be? Collective angst and the desire to protect the ingroup from possible extinction. Keynote speaker at the Royce Conference, University of Alberta, Edmonton, AB, Canada.

Wohl, M. J. A. (2010, March). Terror through collective angst: Why the concern for the future vitality of the ingroup leads to support for aggressive behavior. Invited talk at Ben Gurion University, Be'er Sheva, Israel.

Wohl, M. J.A. (2010, March). Collective angst: Group-based existential concern and the desire to protect the ingroup from possible extinction. Invited talk at the University of Tel-Aviv, Tel-Aviv, Israel.

Wohl, M. J. A. (2010, February). We are sorry: Why official apologies succeed and fail to promote intergroup forgiveness. Invited talk at McGill University, Montreal, QC.

Wohl, M. J. A. (2009, October). Forgiveness between social groups: When intergroup forgiveness is granted and why it is often not. Invited talk at the University of Queensland, Brisbane, Qld, Australia.

Wohl, M. J. A. (2009, June). Existential group-based anxiety: Collective angst as a motivator for ingroup strengthening behaviors. Invited talk at the Social and Personality Section Pre-conference for the $70^{\text {th }}$ Annual Convention of the Canadian Psychological Association (CPA), Montreal, QC. 
Wohl, M. J. A. (2009, October). Forgiveness between social groups: When intergroup forgiveness is granted and why it is often not. Invited talk at the University of Queensland, Brisbane, Qld, Australia.

Wohl, M. J. A. (2009, June). Existential group-based anxiety: Collective angst as a motivator for ingroup strengthening behaviors. Invited talk at the Social and Personality Section Pre-conference for the 70th Annual Convention of the Canadian Psychological Association (CPA), Montreal, QC.

Wohl, M. J. A. (2009, April). Understanding intergroup forgiveness. Invited talk at University of Waterloo, Waterloo, ON.

Wohl, M. J. A. (2009, January). Effective lecturing in Psychology: What to do... and what not to do. Invited talk at Carleton University, Ottawa, ON.

Wohl, M. J. A. (2008, November). Collective angst. Invited talk at Carleton University, Ottawa, ON.

Wohl, M. J. A. (2008, August). Staying alive: The antecedents and consequences of collective angst. Invited talk at Austrlian National University, Canberra, Australia.

Wohl, M. J. A. (2008, January). Can animation-based education correct erroneous cognitions and reduce the frequency of exceeding limits among slots players? Invited talk at the Ontario Problem Gambling Research Centre, Guelph, ON.

Wohl, M. J. A. (2007, December). Is the Future of Your Group Secure? The Antecedents and Consequence of Collective Angst. Invited talk at the University of Queensland, Qld, Australia.

Wohl, M. J. A. (2007, March). Threats to the future vitality of the ingroup: The antecedents and consequence of collective Angst. Invited talk at the University of Ottawa, ON.

Branscombe, N.R., Wohl, M.J.A., \& Warner, R. (2007, January). Reminders of historical victimization: Implications for justifiability of ingroup harm doing in the present. Invited presentation in the Justice and Identity Symposium of the Society of Personality and Social Psychology, Memphis. TN.

Branscombe, N.R., Wohl, M.J.A., Warner, R., \& Klar, Y. (2007, January). Remembering historical victimization: Malleable meanings and implications for actions in the present. Invited presentation at the Group Processes and Intergroup Relations Preconference of the Society of Personality and Social Psychology, Memphis. TN.

Wohl, M. J. A. (2005, November). Personal luck and outcome expectancies as predictors of gambling pathology and readiness to seek treatment. Invited talk at the University of Guelph, Guelph, ON.

Wohl, M. J. A. (2005, October). Threats to the future vitality of the ingroup and the emotional responses of the collective ego. Invited paper presented at the Quiet Ego Conference, Flagstaff, AZ.

Wohl, M. J. A. (2003, January). Understanding well-being and forgiveness following negative life events. Invited talk at Grant MacEwan College, Edmonton, AB.

Wohl, M. J. A. (2001, July). When is to err human? The psychology of guilt and forgiveness. Invited talk for the University of Calgary Social Psychology Social Development Research Group (SPSDRG), Calgary, AB.

Wohl, M. J. A. (2001, February). The rationale for non-rational thought: From heuristics to sympathetic magic. Invited talk at the University of Kansas brown bag, Lawrence, KS

\section{c) presentations to non-academic, community bodies (invited)}

Wohl, M. J. A. (2022, October). Rewarding responsible gambling. Presentation to the Atlantic Lottery Corporation. online.

Wohl, M. J. A. (2022, October). The harm-reduction potential of loyalty programs. Presentation to the Canadian 
Responsible Gambling Association, Montreal, QC.

Wohl, M. J. A. (2022, October). Loyalty programs: The good, the bad, and the ugly. Presentation to the Indiana Council on Problem Gambling, Indianapolis, IND.

Wohl, M. J. A. (2021, March). The psychological science of forgiveness: What is it and when should it be offered? Presentation to the Ottawa-Carleton District School Board, Ottawa, Canada. Online.

Wohl, M. J. A. (2020, November). Addiction substitution among gamblers following casino closures precipitated by the COVID-19 pandemic. Presentation to the general public as part of the MeWERTH Centre launch, Ottawa, Canada. Online.

Wohl, M. J. A. (2020, September). Days of future past: Concerns for the group's future prompt longing for their past. American Psychological Association Podcast.

Wohl, M. J. A. (2020, November). Addiction substitution among gamblers following casino closures precipitated by the COVID-19 pandemic. Presentation at A RACE AGAINST THE CLOCK: Canadian Mental Health Researchers Stand Up to COVID-19 held by Research Canada. Online.

Wohl, M. J. A. (2019, November). Paths to problem gambling and conduits to harm-minimization. Presentation at the Friday Luncheon Discussion Club, Ottawa, ON.

Wohl, M. J. A. (2019, November). Responsible gambling 101: Deep talk about things you need to Know*(*but may be afraid to ask). Presentation to casino staff at the Rideau-Carleton Raceway, Ottawa, ON.

Wohl, M. J. A. (2019, May). Responsible gambling 101: Deep talk about things you need to Know* (*but may be afraid to ask). Presentation to GameSense Advisors during Massachusetts Responsible Gambling Awareness Week, Boston, MA.

Wohl, M. J. A. (2018, May). Rewarding responsible gambling to promote positive play. Presentation to casino staff during the Canadian Responsible Gambling Association meeting, Toronto, ON.

Wohl, M. J. A. (2018, March). Knowledge needs: Players perspective. Presentation to the community at the Provincial Knowledge Needs Committee meeting, Toronto, ON.

Wohl, M. J. A. (2017, October). Loyalty programs in the Gambling Industry. Presentation to the Alberta Gambling and Liquor Commission, Edmonton, AB.

Wohl, M. J. A., Davis, C. G., \& Hollingshead, S. J. (2017, April). Loyalty programs in the gambling industry and their impact on play. Presentation to the Atlantic Lottery Corporation, Moncton, NB.

Wohl, M. J. A. (2016, October). Responsible gambling. Presentation to casino staff at Rideau Carleton Raceway, Ottawa, ON

Wohl, M. J. A., \& Salmon, M. M. (2016, October). The power of looking back: Nostalgia and behaviour change. Presentation to clients at the Alcohol, Drug, and Gambling Services, Hamilton, ON.

Wohl, M. J. A., Davis, C. G., \& Hollingshead, S. (2016, February). An evidence-based approach to RG programming. Presentation casino employees at the Ontario Lottery and Gaming Responsible Gambling Forum, Toronto, ON.

Wohl, M. J. A. (2015, May). Responsible gambling and the impact of social casino gaming. Presentation to treatment providers at the YMCA of Greater Toronto, Ottawa, ON.

Wohl, M. J. A. (2014, September). Atoning for "OUR” Sins? The curious case of the collective apology. Presentation to community at Agudath Israel Congregation, Ottawa, ON.

Wohl, M. J. A. (2010, November). The emotional state of the Jewish Community. Presentation to the community at 
Machzikei Hadas Congragation, Ottawa, ON.

Wohl, M. J. A. (2010, October). Identity under threat: The emotional state of ANSAs. Presentation to Defense and Research Development Canada Understanding Armed Non-State Actors (ANSAs) workgroup. Toronto, ON.

Wohl, M. J. A. (2008, November). Collective angst motivates ingroup protective action. Presentation to Defense Research and Development Canada, Toronto, ON.

Wohl, M. J. A. (2008, September). Understanding forgiveness in an intergroup context. Presentation to Interfaith Panel of Ottawa, Ottawa, ON.

Wohl, M. J. A. (2003, April). Forgiveness: What is it and when is it possible? Presented to community at Philosopher's Café, Edmonton, AB.

\section{Other Important Forms of Scholarly Productivity}

\section{Research Grants}

\section{a) Government or extra-university $($ Total $=\$ 6,700,650.22)$}

1. 2023-2024; International Center for Responsible Gambling; \$30,000; Building better player feedback: An assessment of the responsible gambling utility of the positive play quiz. (Principal Investigator: N. Tabri; CoInvestigator: M. J. A. Wohl, R.T. A. Wood).

2. 2022-2023; Massachusetts Gaming Commission; \$100,000; GameSense Evaluation: A Public Health Approach to Reducing the Risk of Disordered Gambling in Massachusetts. (Principal Investigator: M. J. A. Wohl; Co-investigators: N. Tabri, C. Davis)

3. 2021-2022; International Center for Responsible Gambling; \$30,000; Luck Has Nothing to Do With It: Establishing Evidence to Inform Positive Play, Harm Minimization and Treatment Referral for Lottery Players in Indiana. (Principal Investigator: A. Price; Co-Investigator: M. J. A. Wohl).

4. 2021-2022; Canadian Responsible Gambling Association; \$605,640; Value of Responsible Gambling. (Principal Investigator: R.T. A. Wood; Co-Investigator: K. S. Philander, N. Tabri, M. J. A. Wohl).

5. 2020-2022; Canadian Centre for Substance Abuse and Addiction; \$100,000; Understanding responsible and harmful cannabis use: Rapid evidence assessment and user experience. Principal investigator: M. J. A. Wohl; Co-investigators: A. Stefaniak, N. Tabri, R. Wood)

6. 2020; Gambling Research Exchange Ontario; \$40,000; Population-based safer gambling/responsible gambling efforts. (Principal investigator: N. Tabri; Co-investigators: M. J. A. Wohl)

7. 2020-2022; International Center for Responsible Gambling; Research Grant; \$171,660; Building the evidence base for pre-commitment oriented play management systems: An examination of uptake, selection of a mandatory (versus voluntary) limit adherence option, and behavior change. (Principal investigator: M. J. A. Wohl; Co-investigators: C. Davis, N. Tabri)

8. 2019-2020; Gambling Research Exchange Ontario; \$54,900; Evaluating the effectiveness of My PlaySmart. (Principal investigator: M. J. A. Wohl; Co-investigators: C. Davis)

9. 2019-2024; Social Sciences and Humanities Research Council of Canada; Research Grant; \$229,347; The way (I believe) we were: Collective nostalgia determines the ways people try to reclaim their group's treasured past (Principal investigator: M. J. A. Wohl; Co-investigators: A. Smeekes, C. Sedikides, T. Wildschut)

10. 2018-2019; Gambling Research Exchange Ontario; \$24,052; Disordered gambling and concurrent substance abuse and mental health conditions: A network perspective. (Principal investigator: N. Tabri) 
11. 2017-2020; Ministry of Health and Long-Term Care; \$652,114; Preventing problem gambling in Ontario: Building the Evidence Base for Cultivating Responsible Gambling Knowledge and Habits. (Principal investigator: M. J. A. Wohl; Co-investigator: C. Davis)

12. 2017-2019; Alberta Gambling Research Institute; $\$ 103,333$; Pop-up messages for Internet gambling: An experimental study examining the efficacy of fear appeals. (Principal investigator: D. Hodgins; Co-Principle Investigator: S. Mutti-Packer; Co-investigator: H. Kim, D. McGrath, M. Rockloff, \& M. J. A. Wohl)

13. 2017-2018; Alberta Gambling Research Institute; $\$ 141,490$; Do social casino games encourage gambling? An experimental approach. (Principal investigator: D. Hodgins; Co-investigator: H. Kim, M. Rockloff, \& M. J. A. Wohl)

14. 2017-2018; Gambling Research Exchange Ontario; \$60,000; Gambling research exchange and training (GREaT) hub. (Principal investigator: M. J. A. Wohl)

15. 2016-2017; Gambling Research Exchange Ontario; $\$ 51,600$; What determines uptake of responsible gambling programs? An assessment of OLG's MyPlaySmart enrollment. (Principal investigator: M. J. A. Wohl; Coinvestigator: C. Davis)

16. 2016-2019; Social Science and Humanities Research Council of Canada; Partnership and Development Grants (Community and College Social Innovation Fund); \$240,000; Pathways to radicalization among multicultural youth in Canada. (Principal investigator: J. Caouette; Co-investigators: N. Tabri, R. Ghosh, J. Belanger, \& M J. A. Wohl).

17. 2016-2018; Manitoba Gambling Research Program; Research Grant; $\$ 119,436$ Player information needs: Education and monetary limit adherence (Principal investigator: M. J. A. Wohl; Co-investigator: D. Santesso).

18. 2016-2017; Gambling Research Exchange Ontario; $\$ 75,000$; Gambling research exchange and training (GREaT) hub. (Principal investigator: M. J. A. Wohl)

19. 2015-2017; Gambling Research Exchange Ontario; \$56,172; Assessing the connections program: A new treatment for disordered gamblers. (Principal investigator: M. J. A. Wohl; Co-investigator: A. Kim)

20. 2015-2016; Gambling Research Exchange Ontario; \$97,200; Gambling research exchange and training (GREaT) hub. (Principal investigator: M. J. A. Wohl)

21. 2014-2016; Ministry of Health and Long-term Care (Ontario); \$462,270; Starving to gamble: Hunger, craving, and self-perceptions as harbingers of problem gambling (and responsible gambling solutions). (Principal investigator: M. J. A. Wohl; Co-investigator: A. Abizaid)

22. 2014-2016; Ontario Problem Gambling Research Centre; Research Grant; \$78,720; Assessing the impact of a win/loss tool among Winners Circle members. (Principal investigator: M. J. A. Wohl; Co-investigator: C. Davis).

23. 2014-2016; Manitoba Gambling Research Program; Research Grant; $\$ 128,361.12$; Overcoming barriers to treatment seeking. (Principal investigator: M. J. A. Wohl; Co-investigator: D. Santesso).

24. 2014-2015; National Center for Responsible Gambling; \$27,772.50; Discontinuity and change among disordered gamblers. (Principal investigator: M. J. A. Wohl; Co-investigators: M. Salmon \& H. S. Kim).

25. 2013-2014; Ontario Problem Gambling Research Centre; Research Grant; $\$ 231,726.60$; Play-for-fun to playfor-pay: Identifying factors that transition young adults from social network gaming to online gambling. (Principal investigator: M. J. A. Wohl; Co-investigators: R. Gupta \& J. Derevensky).

26. 2012-2013; Ontario Problem Gambling Research Centre; Research Grant; $\$ 42,000$; Facilitating responsible gambling through persuasive technology: Using Human-Computer Interaction principles to better monetary limit tools. (Principal investigator: M. J. A. Wohl; Co-investigator: A. Parush). 
27. 2012; Ontario Problem Gambling Research Centre; Research Grant; $\$ 55,000$; A qualitative examination of online gambling culture among college students: Factors influencing participation, maintenance and cessation. (Principal investigator: M. J. A. Wohl; Co-investigator: R. Gupta \& J. Derevensky).

28. 2012; Ontario Problem Gambling Research Centre; Research Grant; $\$ 41,535 ;$ Assessment of a short educational animation in reducing erroneous cognitions and facilitating adherence to monetary limits among slot machine gambling: A 30-day Follow-up Study. (Principal investigator: M. J. A. Wohl; Co-investigators: K. Harrigan \& D. Santesso).

29. 2012; Ontario Problem Gambling Research Centre; Research Grant; $\$ 99,960$; Reducing erroneous cognitions and facilitating adherence to monetary limits among slot machine gambling: The creation and assessment of a short educational animations. (Principal investigator: M. J. A. Wohl; Co-investigators: K. Harrigan \& D. Santesso).

30. 2011-2015; Ontario Problem Gambling Research Centre; Research Grant; $\$ 157,680$; The relationship of goal setting, emotional state, and decision making in electronic gaming machine players. (Principal investigator: M. J. A. Wohl; Co-investigator: L. Nower).

31. 2012-2019; Social Sciences and Humanities Research Council of Canada; Research Grant; \$209,990; We were, we are, will we be? Constructive and destructive responses to collective angst. (Principal investigator: M. J. A. Wohl)

32. 2011-2012; Ontario Problem Gambling Research Centre; Research Grant; $\$ 118,137$; Promoting responsible gambling: Assessing the efficacy of initiatives aimed at increasing monetary and time limit adherence among slot machine gamblers. (Principal investigator: M. J. A. Wohl; Co-investigator: M. J. Stewart).

33. 2009-2012; Australian Research Council; Research Grant; \$174,000 AUD; Promoting intergroup forgiveness: The benefits and pitfalls of apologies and invocations of shared humanity. (Chief investigator: M. Hornsey; Partner investigator: M. J. A. Wohl).

34. 2009-2014; Canadian Foundation of Innovation; Research Grant; $\$ 359,171$; The antecedents and consequences of gambling pathology. (Principal investigator: M. J. A. Wohl)

35. 2009-2012; Ontario Problem Gambling Research Centre; Research Grant; $\$ 538,549$; Genetic analysis of the endophenotypes of impulsivity and reward dependence in pathological gambling. (Principal investigator: John Stead; Co-investigators: M. J. A. Wohl, H. Anisman \& K. Matheson).

36. 2008-2011; Social Sciences and Humanities Research Council of Canada; Research Grant; $\$ 92,880$; The antecedents and consequences of collective angst. (Principal investigator: M. J. A. Wohl)

37. 2007-2008; Ontario Problem Gambling Research Centre; Research Grant; $\$ 155,400$; Can animation-based education correct erroneous cognitions and reduce the frequency of exceeding limits among slots players? (Principal investigator: M. J. A. Wohl; Co-investigators: H. Anisman \& K. Matheson)

38. 2006-2009; Ontario Problem Gambling Research Centre; Research Grant; $\$ 434,976$; Appraisals and expectancies in relation to stages in the evolution and cessation of gambling behaviours. (Principal investigator: M. J. A. Wohl; Co-investigators: H. Anisman \& K. Matheson).

39. 2005-2008; Social Sciences and Humanities Research Council of Canada; Research Grant; $\$ 111,768$; Transgenerational effects of ethno-political conflict: How the meaning garnered from historical victimization influences the attitudes and behaviour of subsequent generations. (Principal investigator: M. J. A. Wohl)

40. 2004-2005; Ontario Problem Gambling Research Centre; Research Grant; $\$ 197,310$; Personal luck, outcome expectancies, and subjective appraisals as predictors of health and readiness to seek treatment among young adults. (Principal investigator: M. J. A. Wohl; Co-investigators: H. Anisman \& K. Matheson). 
41. 2001-2002; Alberta Gaming Research Institute; Research Grant; \$1,500; How near wins and near losses affect gamblers' self-perceptions, risk estimations, and future gambling behaviour. (Principal investigator: M. Enzle; Co-investigators: M. J. A. Wohl \& C. Heth).

\section{b) University}

1. 2018-2019; International Research Seed Grant [Carleton University]; \$10,000; Social identity, nostalgia, and recovery from addiction.

2. 2019; Multidisciplinary Research Cluster [Carleton University]; \$10,000; Behaviour change cluster.

3. 2018-2019; International Research Seed Grant [Carleton University]; \$10,000; Discontinuity-induced nostalgia: A novel means to motivate behaviour change among people living with addiction.

4. 2004-2005; GR-6 [Carleton University]; \$3,500; Effects of counterfactuals, blame, and forgiveness, on wellbeing following the end of a romantic relationship.

\section{Service to the Profession}

\section{a) Offices in learned societies}

Ontario Gambling Researcher Society, Co-President, 2018-present

Canadian Psychological Association: Social and Personality Section, Past-Chair, 2007-2008

Canadian Psychological Association: Social and Personality Section, Chair, 2006-2007

Canadian Psychological Association: Social and Personality Section, Chair-Elect, 2005-2006

Canadian Psychological Association: Social and Personality Section, Board Member, 2002-2008

\section{b) Positions held on selection committees or performance adjudication boards}

New South Wales Responsible Gambling Fund, Grant Adjudication Committee, Committee Member, 2019-present International Center for Responsible Gambling, Grant Adjudication Committee, Committee Member, 2019-present Ontario Graduate Fellowship, Panel 31, Committee Member 2008-2010

Social Science and Research Council of Canada, Committee 10, Committee Member 2006-2007

\section{c) Manuscript appraisals for journals or publishers}

Personality and Social Psychology Review, Ad Hoc Review, 2014-present

Social Issues and Policy Review, Ad Hoc Reviewer, 2013-present

Journal of Peace Psychology, Ad Hoc Reviewer, 2011-present

Journal of Gambling Issues, Ad Hoc Reviewer, 2010-present

Social Psychology and Personality Science, Ad Hoc Reviewer, 2010-present

Psychology of Addictive Behavior, Ad Hoc Reviewer, 2009-present

Political Psychology, Ad Hoc Reviewer, 2009-present

British Journal of Social Psychology, Ad Hoc Reviewer, 2007-present

European Journal of Social Psychology, Ad Hoc Reviewer, 2007-present

Journal of Social and Personal Relationships, Ad Hoc Reviewer, 2007-present

Canadian Journal of Behavioural Science, Ad Hoc Reviewer, 2006-present

Journal of Experimental Social Psychology, Ad Hoc Reviewer, 2006-present

Journal of Personality and Social Psychology, Ad Hoc Reviewer, 2006-present

Addiction Research and Theory, Ad Hoc Reviewer, 2005-present

Self and Identity, Ad Hoc Reviewer, 2005-present

Substance Use and Misuse, Ad Hoc Reviewer, 2005-present

Conflict Management and Peace Science, Ad Hoc Reviewer, 2003-present

Group Processes and Intergroup Relations, Ad Hoc Reviewer, 2003-present

International Journal of Psychology, Ad Hoc Reviewer, 2003-present

Journal of Applied Social Psychology, Ad Hoc Reviewer, 2003-present

Journal of Gambling Studies, Ad Hoc Reviewer, 2003-present 
Psychological Science, Ad Hoc Reviewer, 2003-present

Canadian Psychological Association (Annual Conference), Abstract Adjudicator, 2003

Personality and Social Psychology Bulletin, Ad Hoc Reviewer, 2002-present

\section{d) Assessment of research proposals}

Alberta Gambling Research Institute

Manitoba Gambling Research Program

Durand Jacobs Award, Committee Member

International Center for Responsible Gambling

Social Science and Research Council of Canada

\section{e) Assessment of candidates for promotion at other universities}

University of Massachusetts, Department of Psychology, 2021

University of Pittsburgh, Department of Psychology, 2021

University of Nevada, Las Vegas, William F. Harrah College of Hospitality, 2021

McMaster University, Department of Psychiatry and Behavioural Neurosciences, 2019

Tel-Aviv University, Department of Psychology, 2015

Université de Montréal, Department of Psychology, 2015

\section{f) External examiner for MA or Ph.D. theses at other university}

Joshua Guilfoyle (Ph.D.) Department of Psychology. York University, 2020.

Cailynn D. Laprise (MA) Department of Psychology, Laurentian University, 2020.

Angela Ma (MA) Department of Psychology, University of Alberta, 2020.

Brittany Keen (Ph.D.) Department of Psychology, University of Sydney, 2019.

Alex C. Huynh (Ph.D.) Department of Psychology, 2018.

Jing Shi (MA) Rehabilitation Science, University of Toronto, 2018.

Michael Auer (Ph.D.), Department of Psychology, University of Nottingham, 2016.

Roni Porat (Ph.D). Department of Psychology, Hebrew University of Jerusalem, 2016.

Nadia Y. Bashir (Ph.D.) Department of Psychology, University of Toronto, 2015.

Jussi Palmomaki (Ph.D.) Cognitive Science, Institute of Behavioural Science, University of Helsinki, 2014.

Dennis T. Kahn (Ph.D.) Department of Psychology. University of Tel Aviv, 2014.

Jamey L. Lister (Ph.D.) Department of Social Work. Rutgers University, 2014.

Julian Baudinet (Ph.D.) Department of Psychology, University of Sydney, 2012.

Harold W. Willaby. (Ph.D.) Department of Psychology, University of Sydney, 2012.

Aurore Chow (Ph.D.) Department of Psychology. Flinders University, 2012.

Samantha Moskowitz (MA) Lauder School of Government, Diplomacy and Strategy, Interdisciplinary Center Herzliya, 2011.

Dennis Kahn (MA) Department of Psychology, Tel Aviv University, 2010.

Gregory Gunn (Ph.D) Department of Psychology, Wilfred Laurier University, 2010.

\section{g) Other forms of service to the profession}

\section{i) Conferences Organized}

Society for Personality and Social Psychology: Group Processes and Intergroup Relations pre-conference, January $27^{\text {th }}, 2011$, San Antonio, TX, USA.

Canadian Psychological Association: Social and Personality Section Pre-conference, June $7^{\text {th }}$ 2006, Calgary, AB.

Social Psychologists in the Rocky Mountains, July $12^{\text {th }}-13^{\text {th }} 1999$, Calgary, AB.

\section{ii) Symposia Organized}

Wohl, M. J. A. (2016, July). What lies on the road to reconciliation? Chair of symposium presented at the 16th biannual 
International Society for Social Justice Conference, Canterbury, UK.

Wohl, M. J. A., \& Brown, R. P. (2005, January). Frontiers in forgiveness research. Co-chair and co-organizer of symposium presented at the 6th annual meeting of the Society for Personality and Social Psychology (SPSP), New Orleans, LA.

Wohl, M. J. A. \& Sherwood, T. (2004, January). The what's how's and why's of forgiveness: An Interfaith Panel. Coorganizer and moderator. Carleton University, Ottawa, Canada

Wohl, M. J. A. (2003, June). Facing discrimination: Response strategies of disadvantaged groups. Chair/organizer of symposium presented at the 64th Annual Convention of the Canadian Psychological Association (CPA), Hamilton, Ont.

Wohl, M. J. A. (2003, June). New discoveries in social psychology: The "ways" and "whys" of social behavior. Chair/organizer of symposium presented at the 64th Annual Convention of the Canadian Psychological Association, Hamilton, ON.

\section{iii) Symposia discussant}

Wohl, M. J.A. (2006, February). Reconciliation and apology. Symposia discussant at $15^{\text {th }}$ Annual Symposium on Conflict Resolution, Ottawa, ON.

Wohl, M. J.A. (2005, February). Forgiveness. Symposia discussant at $14^{\text {th }}$ Annual Symposium on Conflict Resolution, Ottawa, ON.

\section{iv) Discussion moderator}

Wohl, M. J. A. (2020, July). Replicability, open science, and independence in gambling research [Webinar].

Moderator. Technology, risk and gambling seminar series, University of Sydney. https://www.sydney.edu.au/brainmind/our-research/technology-addiction/gather-webinars.html

\section{v) Workshops}

Wohl, M. J. A. (2022, June). Regards Programs in the Gambling Industry: The good, the bad, and the ugly. Workshop for Indiana Council on Problem Gambling. Indianapolis, IN.

Wohl, M. J. A. (2022, June). Responsible Gaming 101: Deep Talk about Things You Need to Know* (*But May Be Afraid to Ask). Workshop for Funstage. [Virtual]

Wohl, M. J. A. (2022, May). The past can help change the future: Using nostalgia to motivate behavior change. Workshop for the New York Council for Responsible Gambling, [Virtual].

Wohl, M. J. A. (2022, May). Developing discrepancy between the past and present: Leveraging nostalgic reverie to facilitate behavior change among those engaged in addictive behavior. Workshop for the New York Council for Responsible Gambling, [Virtual].

Wohl, M. J. A. (2022, April). On letting go: Addiction, recovery and the psychological of forgiveness. Workshop for the Indiana Council on Problem Gambling, [Virtual].

Wohl, M. J. A. (2021, December). The psychological science of forgiveness: What is it and when should it be offered? Workshop for the Safe Foundation, [Virtual].

Wohl, M. J. A. (2021, October). The psychological science of forgiveness: What is it and when should it be offered? Workshop for the New York Council for Responsible Gambling, [Virtual].

Wohl, M. J. A. (2021, May). The psychological science of forgiveness: What is it and when should it be offered? Workshop for the International Center for Responsible Gambling, [Virtual]. 
Wohl, M. J. A. (2019, May). Responsible gambling 101: Deep talk about things you need to know*(*but may be afraid to ask. Workshop for the Massachusetts Council on Compulsive Gambling, Boston MA.

Wohl, M. J. A. (2018, November). Overcoming barriers to behavioural change among disordered gamblers. Workshop at the National Association for Gambling Studies, Brisbane Australia.

Wohl, M. J. A. (2018, February). Paths to problem gambling and conduits to change. Workshop for the Canadian Counselling Association, Ottawa, ON.

Wohl M. J. A. (2016, November). Overcoming barriers to behavioural Change: The power of nostalgia. Workshop for Canadian Counselling and Psychotherapy Association, Webinar.

Wohl, M. J. A. (2016, May). Promoting Responsible Gambling: Pitfalls and the search for solutions. Workshop at Canadian Partnership for Responsible Gambling meeting, Toronto, ON.

Wohl, M. J. A. (2015, January). Advances in treatment seeking. Workshop at St. John's, NL.

Wohl, M. J. A. (2014, January). Responsible gambling: What casino employees needs to know. Workshop at Red Shores Casino, Charlottetown, PEI.

Wohl, M. J. A. (2014, January). Responsible gambling: What the community needs to know. Workshop at Red Shores Casino, Charlottetown, PEI.

Wohl, M. J. A. (2011, August). Intergroup Emotions and Intergroup Enmity. Workshop at the 2011 EASP Summer School on Intergroup Enmity, Wedendorf, Germany

\section{vi) Partnership activities}

The Bridging Insights Think Tank, Harvard-Kennedy School Negotiation Project, member, 2020-present

Ottawa Gambling Harms Prevention Network, member, 2018-present

\section{vii) Advisory committee}

Massachusetts Gaming Commission, Research Review Committee, 2019-present

Singapore National Council on Problem Gambling, International Advisory Panel, 2021-present

\section{viii) Community}

Kindred Hearts Cambodia (charity), board member, 2011-present

\section{ix) Knowledge mobilization}

Ontario Lottery and Gaming's My PlaySmart, Logic Model delivered to Ontario's Ministry of Health and Long-term Care and Ontario Lottery and Gaming

2018 Nostalgia as a Treatment Technique for Addictive Behaviours, Needs assessment delivered to Gambling Research Exchange Ontario

2018 The Power of Nostalgia, Story board and script delivered to Gambling Research Exchange Ontario

2017 The Power of Looking Back: Nostalgia and Behaviour Change, Plain language summary delivered to Alcohol, Drug, and Gambling Services, Hamilton, ON 
2016 Animation-Based Education as a Responsible Gambling Prevention Tool, Research Snapshot (plain language summary) delivered to Gambling Research Exchange Ontario

2012 Slot machines: What every player needs to know (short form), 3-min educational animation delivered to Ontario Program Gambling Research Centre and Ontario Lottery and gaming

2009 Slot machines: What every player needs to know, 9-min educational animation delivered to Ontario Program Gambling Research Centre and Ontario Lottery and gaming

\section{Consultancies and Contract Research}

1. 2021-2022, Atlantic Lottery Corporation, Enterprise Loyalty Program Review

2. 2017-2018, Canadian Responsible Gambling Consortium; National Validation of the Positive Play Scale.

3. 2017; Nova Scotia Provincial Lotteries and Casino Corporation; Training Evaluation.

4. 2017; British Columbia Lottery Corporation; Positive Play Training Module.

5. 2016-2017; Atlantic Lottery Corporation; The Social Responsibility of Player Rewards

6. 2015-2016; British Columbia Lottery Corporation; Positive Play Index.

7. 2014; Atlantic Lottery Corporation; Skilled bonus at Red Shores Charlottetown: Risks and recommendations associated with inclusion of skilled bonus games on slot machines.

8. 2013; British Colombia Lottery Corporation; Perspective on the Public Health Officer's 2009 Report and its relevance to $B C L C$

9. 2013; Interprovincial Lottery Corporation; Video terminals: What every player needs to know

10. 2013; Atlantic Lottery Corporation; Social Responsibility Assessment

11. 2013; Atlantic Lottery Corporation; Blackjack at Red Shores Charlottetown: An assessment of the risks associated with blackjack play and recommendations for minimizing those risks

12. 2012-2013; Playscan; Evaluating the effectiveness of Playscan as a tool to aid responsible gambling and minimize problematic gambling beahviours (Principal Investigator: R. Wood; Co-investigator: M. J. A. Wohl)

13. 2012; Nova Scotia Gaming Corporation; Assessment of Nova Scotia Gaming Corporation's My-Play System Change Limit Option

14. 2012; British Colombia Lottery Corporation; Assessing pre-commitment: Research ideas aimed at facilitating limit setting and adherence.

15. 2011-2012; Defence Research and Development Canada; Calibrating the armed Non State Actor (ANSA) conceptual framework: The Social Conflict Block. (Principal Investigator: D. Taylor; Co-investigator: M. J. A. Wohl)

16. 2011; Atlantic Lottery Corporation; Atlantic Lottery's proposed player service approach: Review, assessment, and recommendations. 
17. 2010; Defence Research and Development Canada; The psychology of violent conflict in failing states: A review of the scientific literature. (Principal Investigator: D. Taylor; Co-investigator: M. J. A. Wohl)

\section{Academic Responsibilities}

\section{Lifetime summary of research supervision}

\begin{tabular}{|l|l|l|}
\hline & COMPLETED & IN PROGRESS \\
\hline HONOURS THESIS & 35 & 1 \\
\hline MASTER'S THESIS & 18 & 3 \\
\hline MASTER'S RESEARCH ESSAY & 0 & 0 \\
\hline MASTER'S RESEARCH PROJECT & 0 & 0 \\
\hline DOCTORAL & 7 & 2 \\
\hline POST-DOCTORAL & 5 & 0 \\
\hline FULBRIGHT SCHOLAR & 1 & 0 \\
\hline
\end{tabular}

\section{a) Undergraduate courses taught}

PSYC 3406, Psychological Factors in Health and Illness (2004-2006)

PSYC 1306, Diversity in Psychological Worldviews (2003-present)

PSYCHO 241, Social Psychology, Grant MacEwan College (2002) and University of Alberta (2002-2003)

\section{b) Graduate courses taught}

PSYC 5800, Political Psychology and Intergroup Relations (2021-2022)

\section{c) Teaching workshops}

CUASA Fall Teaching Workshops - "Teaching Evaluations: How to make them work for you" Co-presented with Tim Pychyl (Psychology) and Devon Woods (SLALS), October 15, October 29 and November 19, 2004.

\section{d) Supervision - Post-Doctoral (5):}

$2018 \quad 2022$

Anna Stefaniak: Preventing problem gambling in Ontario: Building the evidence base for cultivating responsible gambling knowledge and habits; Funded by Ontario Ministry of Health and Long-Term Care

Nassim Tabri: Preventing problem gambling in Ontario: Building the evidence base for cultivating responsible gambling knowledge and habits; Funded by Ontario Ministry of Health and Long-Term Care

$20162017 \quad$ Nassim Tabri; Knowledge translation and exchange: Gambling; Funded by Gambling Research Exchange Ontario

$20142016 \quad$ Nassim Tabri; Antecedents of collective angst: Perceptions of probability of a future threat to the ingroup, severity of harm posed by the anticipated threat, and collective efficacy to cope with the threat; Funded by a Fonds de Recherche du Quebec Post-Doctoral Fellowship to Tabri.

20132015 Darcy Dupuis; Collective angst in the contexts of immigration and acculturation; Funded by SSHRC Post-Doctoral Fellowship to Dupuis.

$20142016 \quad$ Travis Sztainert; Staving to gambling: The effect of hunger on gambling behaviour. Funded by MOHTLC grant to Wohl 
responses; Funded by SSHRC Post-Doctoral Fellowship to Caouette.

\section{e) Supervision - Ph.D. (9):}

2022 in progress Jenn McNeil; Nostalgia and work-life conflict

2022 in progress Andreanne Veillette, Conspiracy theories and contempt, (Department of Philosophy; co Supervised with David Matheson)

$2017 \quad 2021 \quad$ Samantha Hollingshead; An integrated thesis examining the influence of casino loyalty program membership on gamblers' attitudinal and behavioural loyalty.

20172020

Seyyed Nima Orazani; Support for violent and non-violent collective action. [Cotutelle with University of Massachusetts at Amherst; co-supervisor Bernard Leidner]

$2016 \quad 2022$

Melissa Salmon; Temporal Focus as a Motivator of Self-Directed Change among People Engaging in Problem Gambling Behaviour.

20142020

Blair Aronovitch; A multi-method study of neuropsychological functioning following treatment for pediatric acute lymphoblastic leukemia (ALL) (co-supervised with Philippe Robey)

$2009 \quad 2014 \quad$ Erinn Squires; Moving beyond betrayl: How meaning-making and power promote forgiveness following infidelity.

Travis Sztainert; The role of craving, executive cognitive functioning, and hunger in gambling

20032008

Matthew Young; The desire to gamble.

f) Supervision - M.A. (21):

2021 in progress Mackenzie Dowson; Nostalgia, optimism and relapse among people living with a gambling disorder

2021 in progress Taylor Mclellan; Gender inequality and health

2021 in progress Renee St-Jean; Responsible cannabis use

$2020 \quad$ Isabelle Bossom; Missing the Past Eating Disorder: Exploring The Dark Side of Nostalgia during Eating Disorder Recovery

$2019 \quad 2021$

Alex McCaffrey; Forgiveness contributes to the moral licensing effect in a multiple victim context.

$20182021 \quad$ Hailey DiCaita; 'What Comes After Transmission? Genital Herpes Knowledge, Psychological Adjustment and Sex-Negativity (co-supervised with Peggy Kleinplatz)

$2015 \quad 201$

Samantha Hollingshead; Does pop-up message content matter? An examination of the effectiveness of informing gamblers about their monetary losses on player limit adherence.

$2015 \quad 2017 \quad$ Sara Lidstone; Perceived excessiveness of compensation demands from victimized groups and its consequences for collective guilt and ingroup forgiveness.

$2014 \quad 2016$

Melissa Salmon; Moving disordered gamblers toward change: Implicit 
theories as a potential moderator of the indirect relationship from self-discontinuity to behavioural change through nostalgia.

$20132015 \quad$ Kendra McLaughlin; Being good without God: Moral similarity between theists and atheists leads to collective angst and prejudice against atheists.

2012 Left program Gabrielle Antaya; Collective angst and the normative conflict model.

$20122014 \quad$ Andrew Kim; Longing for the Past: Nostalgia Mediates the Effects of Perceptions of Discontinuity on Readiness to Change.

$20102013 \quad$ Nathalie Gillen; Relational boredom effects self-forgiveness for transgression committed in romantic relationships.

Leo Kiu, Discrimination, coping, and collective action among overweight individual.

$2008 \quad 2010$

Melissa Stewart; Craving, personal luck, and slot machine play.

2008 Left program Michael Grainger; The effects of ingroup threat on collective angst: A Canadian case example.

Erinn Squires; Timing is everything: The time at which an apology is given affects willingness to forgive.

Travis Sztainert; The effects of blocking gambling behaviour on Craving.

Shannon Bennett; Less than human: Infrahumanization and Forgiveness when an Outgroup Harms the Ingroup.

$2005 \quad 2007$

April McGrath; Effects of social ostracism on intergroup forgiveness.

$2005 \quad 2007$

Neil McVicar; Collective angst and intergroup relations: How the fear of the future vitality of the ingroup influences the attitudes and behaviors of group members.

Sarah Leslie; Body image. (Co-Supervised with G. Pollard).

Andrea Thompson; Self-forgiveness and smoking cessation: Does a tendency to forgive the self facilitate smoking addiction.

\section{h) Supervision - Honours (37):}

Grace Gaudette; Who uses GameSense and why?

20212022 Lisa Northy; Using the Past for Change: Nostalgia but not Self-Concept Clarity Mediates the Indirect Effect of a Positive Past on Readiness to Change

Julia France; When the past is fraught with danger: A negative past undermines nostalgia's behaviour change utility

Kate Higgison; Longing to make men great again: Nostalgia for traditional male identity undermines support for gender equality 
$2018 \quad 2019$

$2018 \quad 2019$

$2017 \quad 2018$

$2017 \quad 2018$

2016 left program

$2016 \quad 2017$

$2015 \quad 2016$

$2015 \quad 2016$

$2014 \quad 2015$

$2014 \quad 2015$

$2013 \quad 2014$

$2013 \quad 2014$

$2012 \quad 2013$

$2012 \quad 2013$

$2012 \quad 2013$

$2012 \quad 2013$

$2011 \quad 2012$

$2011 \quad 2012$

$2010 \quad 2011$

$2010 \quad 2011$

$2008 \quad 2009$

$2008 \quad 2009$

$2007 \quad 2008$
Alicia Shameer; Social identity and its influence on how people evaluate the taste in beer

Silas Xuereb; The effects of the normalization of radical political ideologies on political tolerance and collective angst for the right and left

Christina Milani; Rewarding responsible gambling

Sarah Eade; Nostalgia and forgiveness in a romantic relationship

Colleen Mahoney: Empathetic collective angst

Monique Amar: Informed decision making and responsible gambling

Fiona Cooligan; The role of collective autonomy in the LGBTQ+ community

Matthew Atchison: Theists' perceptions of atheists' moral foundations, moral emotions, and distrust of atheists

Travis Kirkwood: Antecedents of collective guilt

Samantha Hollingshead: A new harm reduction strategy for disordered gamblers: The potential benefits of social casino games

Chanel Larche; Predicting the transition from play-for-fun to play-for-pay.

Kaitlyn Chambers; Starving to gamble: The role of hunger in disordered gambling behaviour.

Jennifer Wong; Impact of source on online drug information on perceived harmfulness of cannabis.

Justin Mensen; Animation-based education as a form of problem gambling prevention: Comparing the effect of a 9 minute animation to a shortened 3 minute version.

Alexandria Melvin; Can an apology change the world? The role of intergroup apologies and cross-group friendships on the representation of physical distance.

Danielle Whittmore; The impact of intrusive rumination on forgiveness following infidelity: A Moderated-mediation model.

Mallory Calderwood; Training to forgive.

Nina Hedayati; Time limit-setting pop-up messages as a means to gamble responsibly for slot machine users.

Justin McManus; The effect of animation-based education and pop-ups on monetary limits adherence among recreational gamblers.

Tegan Ford; Do actions speak louder than words? The effects of nonverbal intergroup apologies compared to verbal intergroup apologies on forgiveness.

Joshua Cowie; Intergroup moral obligations.

Kristen Fennell; Infrahumanization and forgiveness.

Michael Grainger; The effects of ingroup threat on collective angst: A Canadian case 
example.

$20072008 \quad$ Zlata Kovaltchouk; Self-Forgiveness and procrastination: Can self-forgiveness harm performance in an academic setting?

20062007 Travis Sztainert; The effects of near wins on craving to gamble.

$20062007 \quad$ Miriam Lyon; Reasons for the episodic cessation of gambling.

$20052006 \quad$ Celina Boule-Perroni; Self-forgiveness, guilt, and shame predicts smokers' stage of behavioural change.

20042005

Anilise Otten; Does forgiving your partner increase subjective feelings of commitment?

$20042005 \quad$ Carolynne Weir; Investigating the effects of self-blame, self-forgiveness, and emotional intelligence in victims of intimate partner abuse: Is self-forgiveness a positive influence on the well-being of abused victims?

$20042005 \quad$ Neil McVicar; Self-forgiveness suppresses negative impact of self-blame on depression and self-esteem.

$20032004 \quad$ Michael Lister; Why we seek forgiveness: A phenomenological study of interpersonal transgression.

\section{g) Supervision - Fulbright scholars (1):}

$2012 \quad 2013 \quad$ Jamie Lister; The relationship of gambling goals and loss/win conditions to chasing behavior during slot machine play

\section{Administrative Responsibilities at Carleton}

\section{a) Department}

Graduate Chair in Psychology, 2017-present

Cognitive Psychology Hiring Committee, 2022

Psychology Tenure and Promotion Committee, 2003-2004, 2008-2009, 2021-2022

Indigenous Mental Health Hiring Committee, 2019

Psychology Graduate Committee, 2004-2014, 2015-2016

Psychology Undergraduate Committee - 2014-2015

Learning Outcomes Committee, 2013-2014

Chair - Graduate Program, 2013-2014

CUASA, Departmental of Psychology Representative, 2003-2009

Centre for Conflict Education and Research, Management Board (Chair of Research), Department of Law, 2003-present

\section{b) Faculty}

Tenure and Promotion Committee (FASS), 2003-2004, 2022

SSHRC standard research grant vetting (FASS), 2005-2013

\section{c) University}

University Promotion Committee, 2019

CFI JELF Adjudication Committee, 2016

First Year Seminar Working Group, 2015-2016

Jewish Issues Committee, 2013-present

Graduate Faculty Board, 2013-2014

Commission on Inter-Cultural, Inter-Religious and Inter-Racial Relations on Campus, 2011-2013 
Research Excellence Fund (REF) Adjudication Committee, 2011- 2013

SSHRC Institutional Grant, Adjudication Committee, 2008-2012

Enrichment Mini-Courses Program, Lecturer - Keynote Address, 2005

Carleton University Experience, Lecturer, 2005-present (Keynote speaker in 2009)

Ontario University Fair, Delegate, 2005 